Illinois State University

ISU ReD: Research and eData

Theses and Dissertations

2-8-2016

\title{
The effects of tile-drain input on a low-gradient agricultural stream in central Illinois: Using a thermal end member mixing model and a statistical analysis approach
}

Zachary David Kisfalusi

Illinois State University, zkisfal@ilstu.edu

Follow this and additional works at: https://ir.library.illinoisstate.edu/etd

Part of the Geology Commons, and the Hydrology Commons

\section{Recommended Citation}

Kisfalusi, Zachary David, "The effects of tile-drain input on a low-gradient agricultural stream in central Illinois: Using a thermal end member mixing model and a statistical analysis approach" (2016). Theses and Dissertations. 576.

https://ir.library.illinoisstate.edu/etd/576

This Thesis is brought to you for free and open access by ISU ReD: Research and eData. It has been accepted for inclusion in Theses and Dissertations by an authorized administrator of ISU ReD: Research and eData. For more information, please contact ISUReD@ilstu.edu. 
THE EFFECTS OF TILE-DRAIN INPUT ON A LOW-GRADIENT AGRICULTURAL STREAM IN CENTRAL ILLINOIS: USING A THERMAL END MEMBER MIXING MODEL AND A STATISTICAL ANALYSIS APPROACH

\section{Zachary D. Kisfalusi}

\section{Pages}

Tile-drains remove excess water from agricultural fields and channel it directly to the nearest surface water body decoupling the system from the natural flow paths. One way to measure the effects tile-drains have on streams is to monitor the alterations in discharge and the thermal energy both upstream and downstream of the input. In the temperate climate, a stream's thermal signature experiences large fluctuations seasonally along with small diurnal changes. In contrast, groundwater temperature does not show these smallscale changes, and the seasonal changes are often muted and lagged in comparison to surface water. This project aimed to quantify any thermal change to the stream caused by the additional flow from a tile-drain with a drainage basin $3 \%$ of the total watershed. Thermal signatures of the streambed, tile-water and groundwater were measured using data loggers recording 15-minute intervals for a year. Temperature readings were collected throughout a 60-meter stretch of the streambed and within the hyporheic zone. The tile has shown a more constant temperature $\left(5-25^{\circ} \mathrm{C}\right)$ than streambed temperatures (nearly $0-30^{\circ} \mathrm{C}$ ) over data collection from January to December of 2015 with 
a lack of diurnal effects, however, seasonal cycles are visible. The streambed temperatures show a spatially consistent relationship throughout the array, which represents uniform thermal conditions in equilibrium. Collectively, the data suggests the tile-drain has no thermal effect on the stream at the discharge rates present at T3. Investigation into the hyporheic zone showed a consistent temperature regime from a depth of 0.1-0.4 m beneath the streambed; $5-10^{\circ} \mathrm{C}$ at the coldest and $16-26^{\circ} \mathrm{C}$ at their warmest. The hyporheic zone temperatures are not controlled by the groundwater $\left(12-16^{\circ} \mathrm{C}\right)$ with colder temperatures throughout the winter and warmer ones during the summer. These data indicate that the hyporheic zone is controlled by surface water processes and less by upwelling from the groundwater with spatial heterogeneities of the streambed present.

KEYWORDS: Agriculture, Anthropogenic Impacts, Conduction, Groundwater-Surface Water Interactions, Hyporheic Zone, Streams, Temperature, Tile-Drains 
THE EFFECTS OF TILE-DRAIN INPUT ON A LOW-GRADIENT AGRICULTURAL STREAM IN CENTRAL ILLINOIS: USING A THERMAL END MEMBER MIXING MODEL AND A STATISTICAL ANALYSIS APPROACH

ZACHARY D. KISFALUSI

A Thesis Submitted in Partial Fulfillment of the Requirements for the Degree of

MASTER OF SCIENCE

Department of Geography-Geology

ILLINOIS STATE UNIVERSITY

2016 
C 2016 Zachary D. Kisfalusi 
THE EFFECTS OF TILE-DRAIN INPUT ON A LOW-GRADIENT AGRICULTURAL STREAM IN CENTRAL ILLINOIS: USING A THERMAL END MEMBER MIXING MODEL AND A STATISTICAL ANALYSIS APPROACH

ZACHARY D. KISFALUSI

COMMITTEE MEMBERS:

Eric Peterson, Chair

Catherine O’Reilly

Dagmar Budikova 


\section{ACKNOWLEDGMENTS}

The writer wishes to thank many people. First, I would like to thank the Illinois State University Department of Geography-Geology for believing in my abilities as a scientist when accepted in the spring of 2014. Without the support of the faculty and staff, my experience at ISU would not have been as fulfilling. Many of you have been helpful in classes, with my project, or in the field. Special thanks to Jonathan Thayn for help with my heat map. Thank you to Karen Dunton for always telling it like it is and encouraging me to push my limits.

Thank you goes to my committee: Eric Peterson, Catherine O'Reilly, and Dagmar Budikova. I have appreciated the feedback and support that each of you have shown me throughout my two years in the program. I must thank my advisor, Eric Peterson, separately. I have appreciated all the time and effort you have poured into my project and into me personally. I will look back fondly upon how many conversations about hydrogeology and sports. I am very grateful for applying to this program and having you as my mentor. Here is to a round of golf in the future.

I'd also like to thank my undergraduate advisor, Patricia Beddows of Northwestern University, for helping me through the process of graduate school applications and furthering my abilities as a scientist. Many of the things that you taught me for my undergraduate thesis set the foundation for this stage of my life. 
This project would also not be possible without the financial and field support I received. Thank you to the Geological Society of America, the Illinois Groundwater Association, the Illinois State University Graduate School, and the Illinois State University Department of Geography-Geology for funding my project. Many people have helped me in the field from graduate students to undergraduates. I thank all of you for your support inside the stream. A special thank you goes to the T3 team which worked tirelessly during the summer 2015: Kelly Sanks, Tyler Rothschild, and Tamru Taye. Tamru you have been everything I could have imagined as a field partner and more importantly as a friend.

Thank you to all my friends, both near and far, who have kept me sane and allowed me to forget the stress of my thesis from time to time. Special thanks to all the graduate students in the Hydrogeology program over the last two years that have made my time in Normal wonderful. Here is to all the good time inside and outside of Felmley.

Lastly, I must thank my parents and my brother for supporting me in this endeavor to further my education and listening to all my stories about temperature and streams. I can never thank the three of you enough, but I hope this is a start.

Z. D. K. 


\section{CONTENTS}

$\begin{array}{lr}\text { ACKNOWLEDGMENTS } & \text { i } \\ \text { CONTENTS } & \text { iii } \\ \text { TABLES } & \text { v } \\ \text { EQUATIONS } & \text { vi } \\ \text { FIGURES } & \text { vii } \\ \text { CHAPTER } & \end{array}$

I. INTRODUCTION 1

Background 1

$\begin{array}{ll}\text { Statement of the Problem } & 7\end{array}$

$\begin{array}{ll}\text { Research Questions } & 10\end{array}$

\begin{tabular}{ll} 
II. & METHODS \\
\hline
\end{tabular}

Site Description $\quad 12$

$\begin{array}{ll}\text { Data Obtainment } & 14\end{array}$

$\begin{array}{ll}\text { Data Analysis } & 18\end{array}$

III. RESULTS 22

$\begin{array}{ll}\text { Stream Discharge } & 22\end{array}$

Stream Temperature $\quad 29$

Thermal Impact of Tile-Water 31

Thermal Impact of Groundwater 33

IV. DISCUSSION 35

Hydrologic Influence $\quad 35$

Thermal Impact of Tile-Water 36

Thermal Impact of Groundwater 39 
V. CONCLUSIONS

REFERENCES 


\section{TABLES}

$\begin{array}{lll}\text { Table } & \text { Page }\end{array}$

1. Descriptive Statistics for Discharge Data for Both Tile-Flow Conditions 23

2. Regression Statistics for Tile Flow and Non-Tile Flow Models 26

3. Paired T-Test Results of Significance Between Upstream and Downstream Discharge for Tile Flow and Non-Tile Flow Models 


\section{EQUATIONS}

$\begin{array}{lll}\text { Equation } & \text { Page }\end{array}$

1. Thermal Mass Balance Equation 20

2. Algebraic Alteration to Find Theoretical Mixing Temperature 20

3. Algebraic Alteration to Find Theoretical Tile-Discharge 20 


\section{FIGURES}

Figure $\quad$ Page

1. Conceptual Model of How Stream Water and Groundwater Mix and Interact in the Hyporheic Zone 4

2. Model Shows the Thermal Impacts on the Hyporheic Zone 5

3. Conceptual Model of How Tile-Drain Flow Impacts the Hydrologic Cycle in Agricultural Areas

4. T3 Study Site and Watershed Location in Central Illinois 14

5. Schematic of Study Site and Locations of Data Collection 17

6. Schematic of Hyporheic Zone Wells 18

7. Comparison of Stream Discharge in the Absence or Presence of Tile Flow at Upstream and Downstream Locations 24

8. Correlation Between the Upstream and Downstream Discharge 25

9. Linear Regression of Downstream Discharge Predicting Upstream Discharge During Tile Flow Conditions

10. Linear Regression of Downstream Discharge Predicting Upstream Discharge During Non-Tile Flow Conditions

11. Comparison of the Difference in Stream Discharge Between the Upstream $(\mathrm{Qu})$ and the Downstream (Qd) Dependent on Tile Flow

12. Heat Map Depicted by Set Color Ranges Along Streambed

13. Time Series Compilation of Precipitation, Air Temperature, Stream Temperature, Groundwater Temperature, and Tile-Drain Temperature

14. Thermal Envelopes Show the Coldest and Warmest Temperatures for the Three Hyporheic Wells 


\section{CHAPTER I \\ INTRODUCTION}

\section{Background}

Water resources are an ever-growing concern for our world today as both the quality and quantity of the supply are decreasing as a result of human development and interference (WWAP, 2012). Land-use, population growth, climate change, contaminant transport, and economic policy continue to impact how humans look at water resource management (Maguffin, 2006). Water quality is decreased from anthropogenic influences, such as contaminant runoff of chloride or nitrate, entering an aquifer or surface water body; therefore, understanding the amount of runoff and its effect on the drinking supply must be understood (Poole and Berman, 2001; Winter, 1999; Keery et al., 2007; Sophocleous, 2002; Contant Jr., 2004; Harris, 2008). The hydrologic cycle around streams is decoupled from its natural paths through flood prevention and the channelization of streams, depletion of groundwater aquifers, and creation of artificial lakes. The anthropogenic alterations add increased complexity to understanding how different places of water storage interact with one another.

The hydrologic cycle is driven by climatic patterns, physical properties of the area, i.e. geologic material/medium and topography, gravity, and the physical properties of water. (Winter, 1998). When evaluating quality and quantity, an essential component of the hydrologic cycle to examine is the interaction between streams and groundwater. 
The connection between the various reservoirs in the hydrologic cycle increases the complexity in understanding how streams not only interact with the atmosphere but also with the surrounding area through direct subsurface water flow, contaminant transport, and the transfer of thermal energy. Streams experience vertical and horizontal exchange of water throughout the water column with recharge from groundwater and meteoric water (Beach, 2008; Dahl et al., 2007). Streams and groundwater aquifers were once thought of as separate systems; now they are considered to be connected (Winter, 1998; Dahl et al., 2007; Keery et al., 2007; Sophocleous, 2002; Baskaran et al., 2009).

The exchange of water and energy between a stream and the surficial aquifer are examined during baseflow and storm flow conditions. Storm flow, often referred to as event flow, is associated with direct precipitation or snow melt that enters the stream (Sophocleous, 2002; Keery et al., 2007; Dogwiler, 2005; Luhmann, 2010; Oware, 2010). During storm events, the groundwater influence is muted by the overall increase in the total stream water with a larger proportion of meteoric water in the water column. The remainder of the water column is referred to as baseflow, which is provided mostly from groundwater input into the stream (Sophocleous, 2002; Winter, 1999, Bastola, 2011). Groundwater inputs may occur as point sources, such as springs, or diffusely along the streambed. The identification of groundwater flow paths reflects whether the aquifer is being recharged from the stream or if the groundwater is adding to baseflow within the stream (Winter, 1998; 1999). Losing stretches are areas in which the stream water loses volume to the underlying aquifer below. If the stream is increasing in volume from the aquifer, the stream is referred to as gaining. 
The hyporheic zone is the principal zone of mixing between groundwater and surface water bodies; in streams, the zone is located directly under the stream bed and beneath the banks (Winter, 1999; Harris, 2008). In low-gradient agricultural streams, the hyporheic zone has been reported up to a depth of 1.5 meters (Oware, 2010). However, the depth of the hyporheic zone varies upon geology, stream morphology, and hydrologic conditions. The zone depicts the subsequent recharges and/or discharges between the stream and the groundwater (Beach, 2008) (Figure 1). The subsurface flow paths created by the exchange of fluxes allows for the constant transport of solutes and energy across the surface water-groundwater boundary. The hyporheic zone serves as a place of transient storage for the stream, where water and heat are stowed (Burkholder et al., 2008).

Within the hyporheic zone, the majority of mixing is expected to take place in the top $30 \mathrm{~cm}$ beneath the stream (Winter 1998), but temporal effects are seen with a limited amplitude up to a depth of 1.5 meters (Anderson, 2005; Silliman and Booth, 1993). The hyporheic zone varies seasonally and after large magnitude storm events that bring large sudden changes in stream discharge (Beach, 2008). The cyclical nature of temperature in the hyporheic zone is not as prominent as in the overlying streams with the signatures muted and lagged with an increase in depth (Anderson, 2005); losing stretches will exhibit a thermal signature more similar to surface water signature as compared to gaining sections where the surface water signatures is overprinted by the upwelling groundwater. Quantifying water fluxes has proven difficult in the hyporheic zone, but streambed monitoring and well installation beneath the streambed are used to understand the process of mixing (Oware, 2010; Bastola, 2011). 


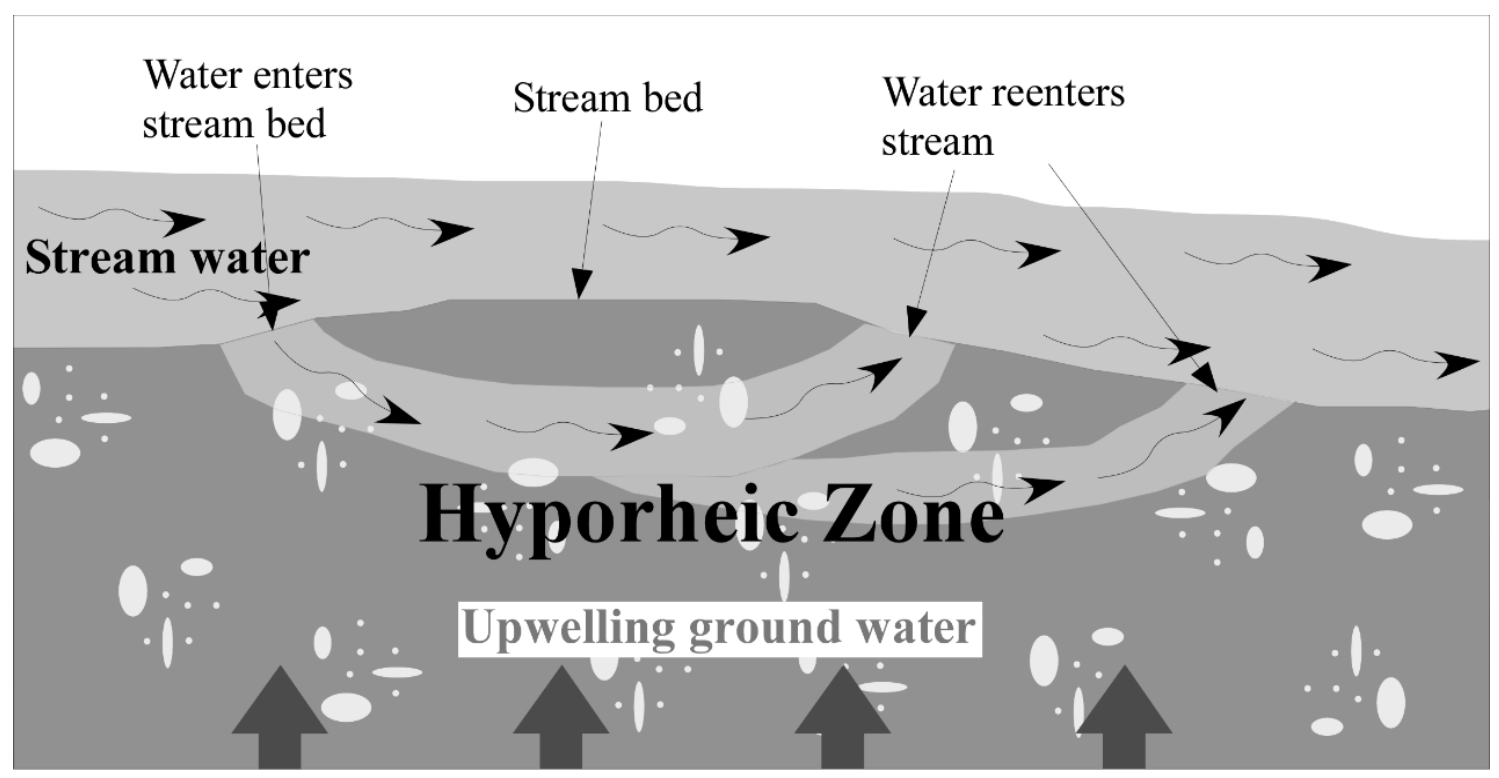

Figure 1. Conceptual model of how stream water and groundwater mix and interact in the hyporheic zone (Beach, 2008).

Temperature is commonly used as a proxy or tracer to correlate the thermal fluxes and to better understand how streams interact with the underlying aquifer systems (Lowry et al., 2007; Keery et al., 2006; Baskaran et al., 2009; Beach and Peterson, 2013; Cassie et al., 2014; Hatch et al., 2006, Anderson, 2005; Beach, 2008). Heat fluxes are increasingly used in rivers as a way to understand changing thermal regimes from climatic and anthropogenic influences (Burkholder et al., 2008). Streams have thermal inputs from groundwater recharge, solar radiation, air temperature, and upstream inputs; all of which contribute to the output of the downstream system (Figure 2) (Winter, 1998; Keery et al., 2007; Hatch et al., 2006; Loheide and Gorelick, 2006). The analysis of subsurface temperatures in the hyporheic zone provide information about the seepage flux that can then be used to determine the gaining or losing influence on the stream (Keery et al., 2007). The hyporheic zone temperature is influenced by external drivers (solar radiation, air temperature, and groundwater input) along with several internal drivers, such as streambed 
conduction and hyporheic exchange with the stream (Burkholder et al., 2008). The hyporheic zone acts as a thermal buffer for the aquifer from surface water variation on various temporal scales (Dogwiler and Wicks, 2006). Heat provides an easily attainable vehicle to map preferred flow paths through the aquifer as heat disperses through conduction or advection (Stonestrom and Constantz, 2004; Ronan et al., 1998; Cassie et al., 2014).

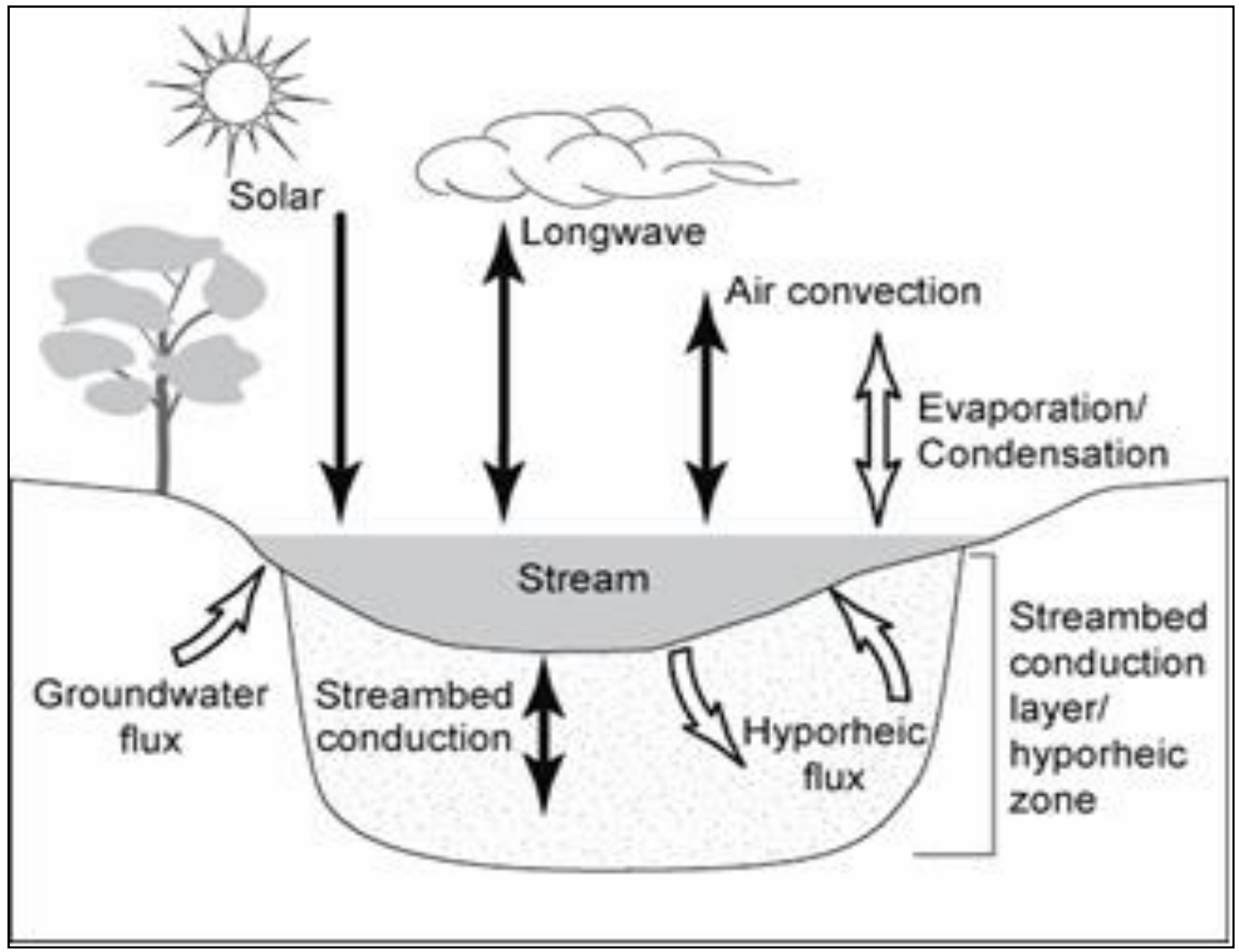

Figure 2. Model shows the thermal impacts on the hyporheic zone. The water (white arrows) and thermal (black arrows) fluxes that affect streambed temperatures are depicted (Loheide and Gorelick, 2006). 
Spatial variability of the fluxes between groundwater and surface water are dependent upon several factors, such as stream stage, hydraulic head gradient, hydraulic conductivity of the channel bed, or additional flow from anthropogenic inputs such as storm sewers or tile-drains (Keery et al., 2007; Hatch et al., 2006; Lowry et al., 2007; Glennon, 2008; Sickbert, 2004; Maguffin, 2006; Hayden, 2012; Theesfeld, 2014; Harris, 2008). The relationship between streambed seepage and changes in the phase and amplitude of thermal waves moving from the stream to the hyporheic zone and vice versa influences how temperature controls this dynamic system (Figure 2) (Hatch et al., 2006). In regards to temperature and water chemistry, streams are more sensitive to change or alteration from added inputs or drastic shifts in antecedent conditions during low flow conditions (Hatch et al., 2006) than groundwater. The altering of fluxes, such as thermal energy, can thus be used as a proxy for seepage rate of groundwater (Keery et al., 2007; Anderson, 2005). Points of upwelling or downwelling are areas of interaction between the stream and groundwater. Spatial differences among streambed temperatures identify areas of mixing and interaction (Contant Jr., 2004). If there are no point sources of interaction, the stream section studied reflects diffuse flow and is spatially consistent (Contant Jr., 2004; Dahl et al., 2007; Lowry et al., 2007).

The temporal variation of temperature is sinusoidal in nature on both diurnal and seasonal scales. Longwave and shortwave solar radiation drive the thermal energy in stream (Loheide and Gorelick, 2006; Diabat et al., 2013). The more substantial seasonal changes in the temperature profile are more reflected in the streambed temperature with a more direct response to weather and climate than the groundwater (Cassie et al., 2014) or hyporheic waters (Dogwiler and Wicks 2006). Silliman and Booth (1993) found that 
groundwater temperature is relatively stable and stream water temperature is more variable as a result of fluctuations of solar radiation causing both diurnal fluctuations and seasonal variations from weather patterns and climatic influences (Lee et al., 2013; Baskaran et al., 2009). Diurnal cycles show variations of less than $1.0-2.0^{\circ} \mathrm{C}$ at shallow depths into the hyporheic zone versus $5-10{ }^{\circ} \mathrm{C}$ in the water column (Silliman and Booth, 1992; Baskaran et al., 2009; Ronan et al., 1998). This idea proved the muted nature of the hyporheic zone, where the lack of direct solar radiation limits the thermal variation of the water as it interacts with the surrounding soils and more stable groundwater (Beach, 2008; Keery et al., 2007). A thermal envelope depicts the muted relationship as it creates a containing casing that surrounds the smoothed-out diurnal oscillations of the surface water and the out of phase hyporheic zone to approximate the seepage flux (Keery et al., 2007; Lapham, 1989). Losing streams will show a greater depth for the warmest and coldest temperatures to converge (Anderson, 2005), while gaining streams show a more consistent thermal signature with a shallow equilibrium point.

\section{Statement of the Problem}

The US Midwest is an area heavily devoted to agriculture, where the production of row crops, soybeans and corn, is aided by fertilization and the installation of tile drainage networks (Skaggs et al., 1994). The introduced fertilizers, primarily nitrate and phosphate, promote plant growth but in excess, lead to negative effects. Excess nitrate is toxic for human consumption when the EPA maximum contaminant level (MCL) of $10 \mathrm{mg} / \mathrm{L}$ nitrate as nitrogen is exceeded (Self and Waskom, 2013). Elevated nitrate concentrations lead to eutrophic and hypoxic conditions, severely impacting the aquatic environments (Poole and Berman, 2001). In Illinois, the majority of the land used for agriculture, 90\%, (White et al., 
2003) used to be prairie and wetlands. The soils lack the natural ability to drain the landscape effectively of surface runoff and stagnated water from storm events (White et al., 2003). Headwater streams are channelized in nearly 80-100\% of central Illinois (Urban and Rhoads, 2003) in one attempt to improve surface drainage. Channelization of streams has been shown to increase peak discharge and decrease the time to a peak hydrologic response to a rainfall event (White et al., 2003).

The alternative is to improve infiltration. To increase subsurface drainage, tile drains are installed a meter or two beneath the surface to lower the water table and increase the infiltration of precipitation (Skaggs et al., 1994). Carried by the soil waters, unutilized $\mathrm{N}$-fertilizer is transported to the subsurface and intercepted by tile-drains, which discharge directly into streams. The tile-drains increase the drainage of soils to insure maximum crop yields, but these manmade channels decouple the natural uptake of nutrients by plants (Klaus, 2014), the chemical transformation of nitrogen, and the absorption into the soil before and at the riparian zone (Hill, 1996). With this nutrient cycle cut off, harmful forms of nitrogen are being flushed into streams and lakes in agricultural areas. Tiles do not flow consistently throughout the year with a dependence on the amount of precipitation and effectiveness to drain the field (Figure 3), but can cause changes when they discharge water into surface water bodies (De Schepper et al., 2015) when transported effectively without any interaction with the riparian zone. The flow from the tile-drain directly discharges into the stream and decouples the natural system within the water column where groundwater, meteoric water from precipitation, and anthropogenic inputs mix (Beach and Peterson, 2013; Lee et al., 2013; Harris, 2008; Klaus, 2014). 
An issue for better understanding agricultural streams is the lack of quantification concerning the water from tile-drains (Bastola, 2011; Skaggs et al., 1994). The abundance of these manmade conduits entering streams per watershed, the amount of discharge from each tile, and the drainage area are all unknown factors involving the complex nature of agricultural streams (Delsman et al., 2014). The chemical analysis on tile-water altering stream processes is well-studied with the impact of nitrates and herbicides a concern throughout the tiled Midwest (Gentry et al., 2000). However, the input from these tileswater also carries a unique thermal signature that can be easily traced through understanding the temporal and spatial variation of heat throughout the system (Zajicek et al., 2011). Heat thus serves as a proxy for the tile- water influence on the system and lead to further investigation of the nutrient input to the stream and hyporheic zone at a cheaper cost. The mixing of the system determines the driving force based on this observed gradient in the streambed temperature versus that of the tile-drain input or the groundwater aquifer. 


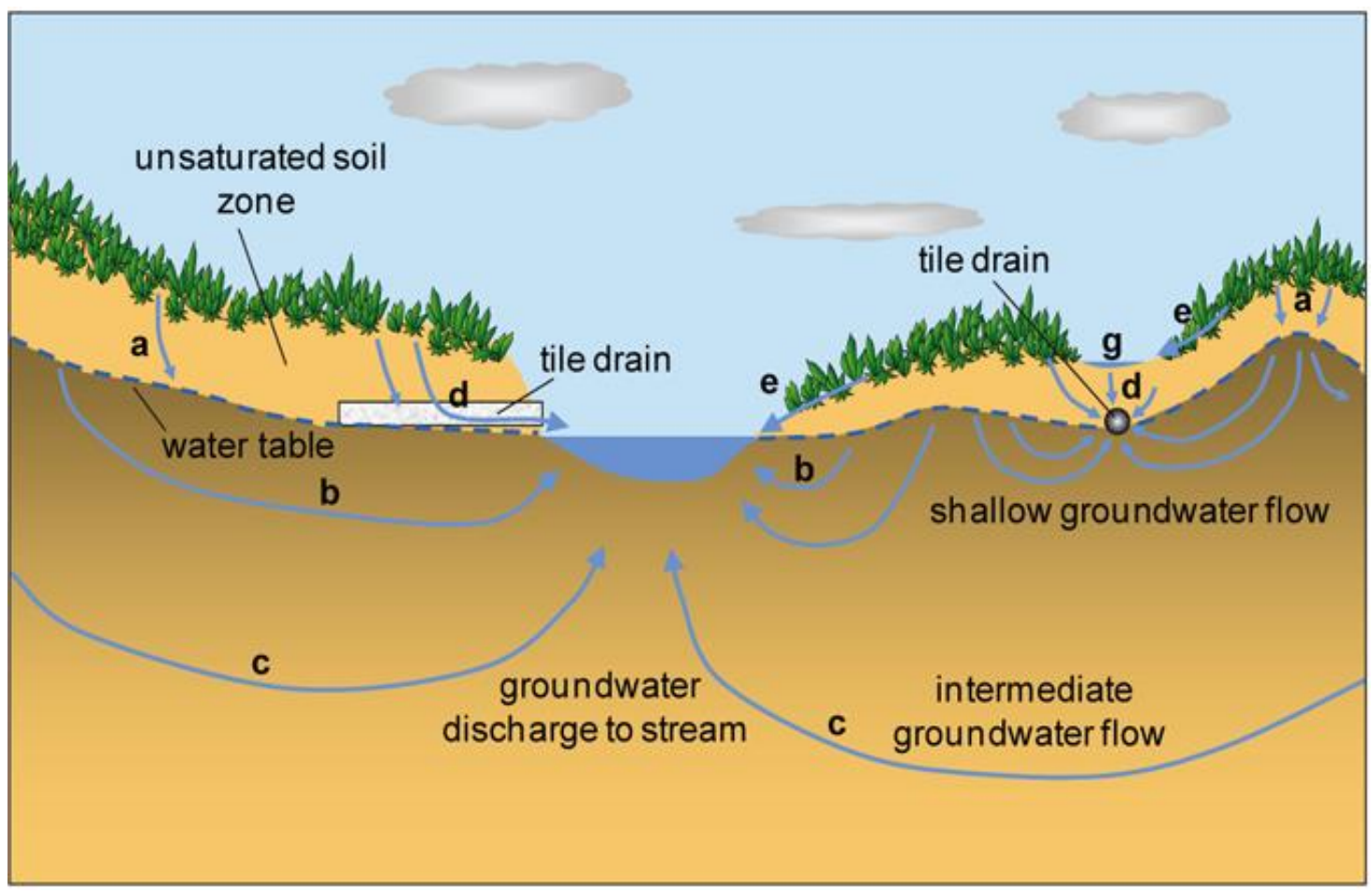

Figure 3. Conceptual model of how tile-drain flow impacts the hydrologic cycle in agricultural areas (USGS, 2009).

\section{Research Questions}

This study aims to better understand the impact of a tile-drain on agricultural streams by quantifying the hydrologic relationship upstream and downstream of the input.

1) Does the tile-drain hydrologically affect the stream?

If the stream is affected by the tile-drain, the average stream discharge will increase downstream of the input. The higher discharge downstream of the input will be indicative of an additional input compared to the upstream segment, thus $\mu_{D} \neq \mu_{U}$.

2) When tile is flowing, a hydrologic effect is known on the stream. Then what is the thermal impact? 
Once a hydrologic effect is confirmed, the thermal impact of tile-water will be quantified to the streambed temperatures.

A) Is the thermal impact of the tile-drain detectable?

If the tile-water does have a thermal impact on the stream, the downstream temperatures observed along the streambed will be altered. The disparity in discharge between the tile-drain and the stream leads me to hypothesize that the temperature signature of the tile-drain input would not be seen in the thermal signature of the stream.

B) Is the thermal impact of the groundwater detectable?

The thermal effects on the groundwater will then be correlated to streambed temperatures. When tile is not flowing, I hypothesize groundwater upwelling should alter streambed temperatures but the hyporheic zone will act as a buffer for the stream from the groundwater upwelling. 


\section{CHAPTER II}

\section{METHODS}

\section{Site Description}

The study site is a restored segment of an agriculturally modified, low-order, stream, T3, and the underlying surficial aquifer in central Illinois (Figure 4). T3 has a drainage area of 1025 hectare and an average discharge of $0.13 \mathrm{~m}^{3} / \mathrm{s}$. T3 has reintroduced riffs and pools downstream of the instrumented portion of the streambed. Along the studied segment is one tile-drain input. The surficial aquifer is unconfined and contained within the glacial till deposits of the Wisconsin glaciation and Holocene alluvium deposits (Johnson and Hansel, 1999). The streambed is comprised of the Cahokia Formation, the Holocene alluvium. Underlying the alluvium and the area away from the stream is the Wedron Group, a blue to grey diamicton with a medium-grained (3.9-62.5 $\mu \mathrm{m})$ mud matrix that oxidizes yellow-brown (Weedman et al., 2014). The Wedron Group lies 50 centimeters beneath streambed and overlies the Silurian dolomite bedrock (Johnson and Hansel, 1999).

The climate is temperate in nature with precipitation year round and average monthly temperatures varying by $30^{\circ} \mathrm{C}$ dependent on season (Changnon et al., 2004). Mean annual air temperature for the last 60 years was $11.2{ }^{\circ} \mathrm{C}$ (Beach, 2008; Peterson and Sickbert, 2006). The average monthly precipitation 
for the last 40 years was highest in spring and lowest in winter with a yearly average of $950 \pm 100$ mm (Bastola, 2011; Changnon et al., 2004).

The 26.3-hectare farm is approximately 120 meters to the east of T3. A tile diversion system was installed recently to manipulate how much tile water directly enters T3 (Figure 5). Tile water was diverted in July 2015 into 3 separate channels in the herbaceous riparian zone 20-35 meters east of the stream. Tile diversion allows for a more natural infiltration process as tile water is reintroduced into the shallow groundwater aquifer. The tile-drainage area for this study is estimated at roughly $3 \%$ of the total watershed area, 1025 hectare, of the low-gradient stream. The regional groundwater gradient is from SE to NW towards the Mackinaw River at $0.0288 \mathrm{~m} / \mathrm{m}$. This study assumes the upwelling groundwater that feeds T3 is constant throughout the year. 


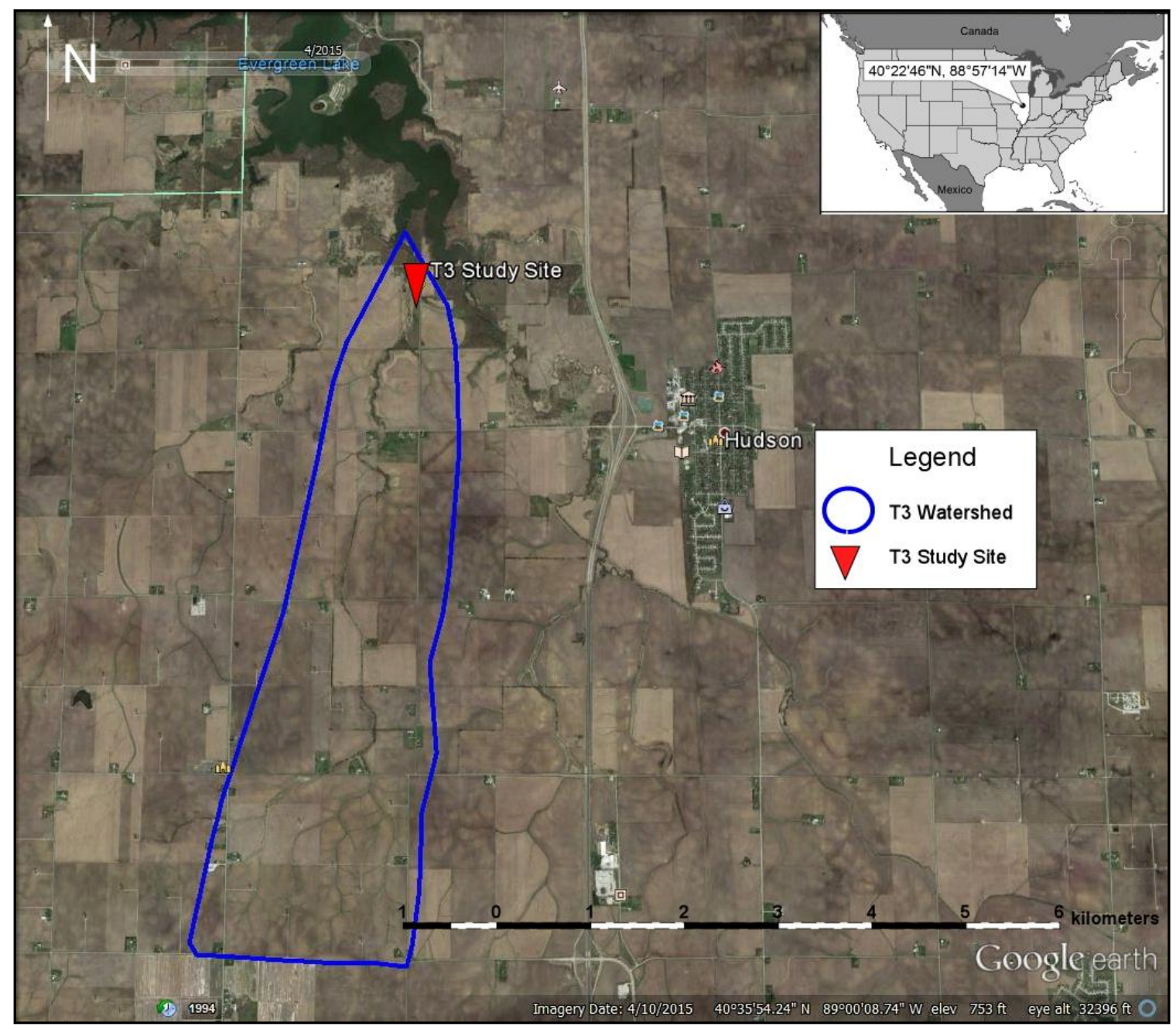

Figure 4. T3 study site and watershed location in central Illinois

\section{Data Obtainment}

This project answers the hydrologic impact of the tile-drain on the stream by measuring the overall flow, or discharge of the stream and the tile-drain itself. Stream discharge $(\mathrm{Q})$ was measured using a flow meter at three locations: the start of the array; perpendicular to the tile-drain input in the main channel; and the end of the array (Figure 5), using the velocity-area method commonly used by the USGS (Sickbert and Peterson, 2014; Lapham, 1989; Contant Jr., 2004; Keery et al., 2006; Glennon, 2008; Sickbert, 2004). 
These localities were chosen to see how the stream discharge differed upstream and downstream of the tile-drain input. Twenty-eight (28) discharge measurements between the downstream and upstream locations were compared pre and post-tile diversion from June 11 to December 10, 2015. Streamflow velocity was measured using a handheld, Sontek Flowtracker Acoustic Doppler Velocimeter (ADV®), velocity range $-0.001 \mathrm{~m} / \mathrm{s}$ to $4.5 \mathrm{~m} / \mathrm{s}$ with an accuracy of $0.0025 \mathrm{~m} / \mathrm{s}$ and a resolution of $0.0001 \mathrm{~m} / \mathrm{s}$. Discharge of the tile-drain was obtained using a five-gallon bucket and a stopwatch when flow to the stream was present from June 11 to July 17, 2015.

This project used temperature, an effective proxy to distinguish mixing (Constantz et al, 2003a; Constantz et al., 2003b; Constantz and Stonestrom, 2003), collected on a 15minute interval to quantify the overall influence of the tile-water and groundwater on surface water temperatures observed along the streambed. Stream water temperatures were measured using an array of $120 \mathrm{HOBO} 囚$ Pendant Data Loggers (at $25^{\circ} \mathrm{C}$, accuracy: $\pm 0.53^{\circ} \mathrm{C}$; resolution: $0.14^{\circ} \mathrm{C}$ ) placed on the streambed. The loggers were positioned at a spacing of 0.5 meter in succession to obtain a longitudinal, thermal signature of the streambed from December 14, 2014 to October 10, 2015 (Figure 5). A HOBO® Water Level Logger (at $25^{\circ} \mathrm{C}$, accuracy: $\pm 0.44^{\circ} \mathrm{C}$; resolution: $0.10^{\circ} \mathrm{C}$ ), was placed in the tile diversion control box about 30 meters up gradient of the stream bed to measure the temperature of the tile-water from January 20 to December 10, 2015.

Three wells were installed in the streambed to a depth of 0.5 meters to examine the thermal regime of mixing in the hyporheic zone from May 10 to December 10, 2015. In each of the wells, four temperature loggers were placed at depths of $0.1 \mathrm{~m}, 0.2 \mathrm{~m}, 0.3 \mathrm{~m}$, 
and $0.4 \mathrm{~m}$ (Figure 6). Following the design of Beach and Peterson (2014), holes were drilled at corresponding depths to allow for thermal equilibrium with the surrounding sediment in the hyporheic zone. The thermal signature of the groundwater was also recorded by a $\mathrm{HOBO}{ }^{\circledR}$ Water Level Logger in a groundwater well east of the stream in the riparian zone from July 1 to December 10, 2015 (Figure 5); the well was screened at a depth of 1.52 meters ( 5 feet), the location of the water table. 


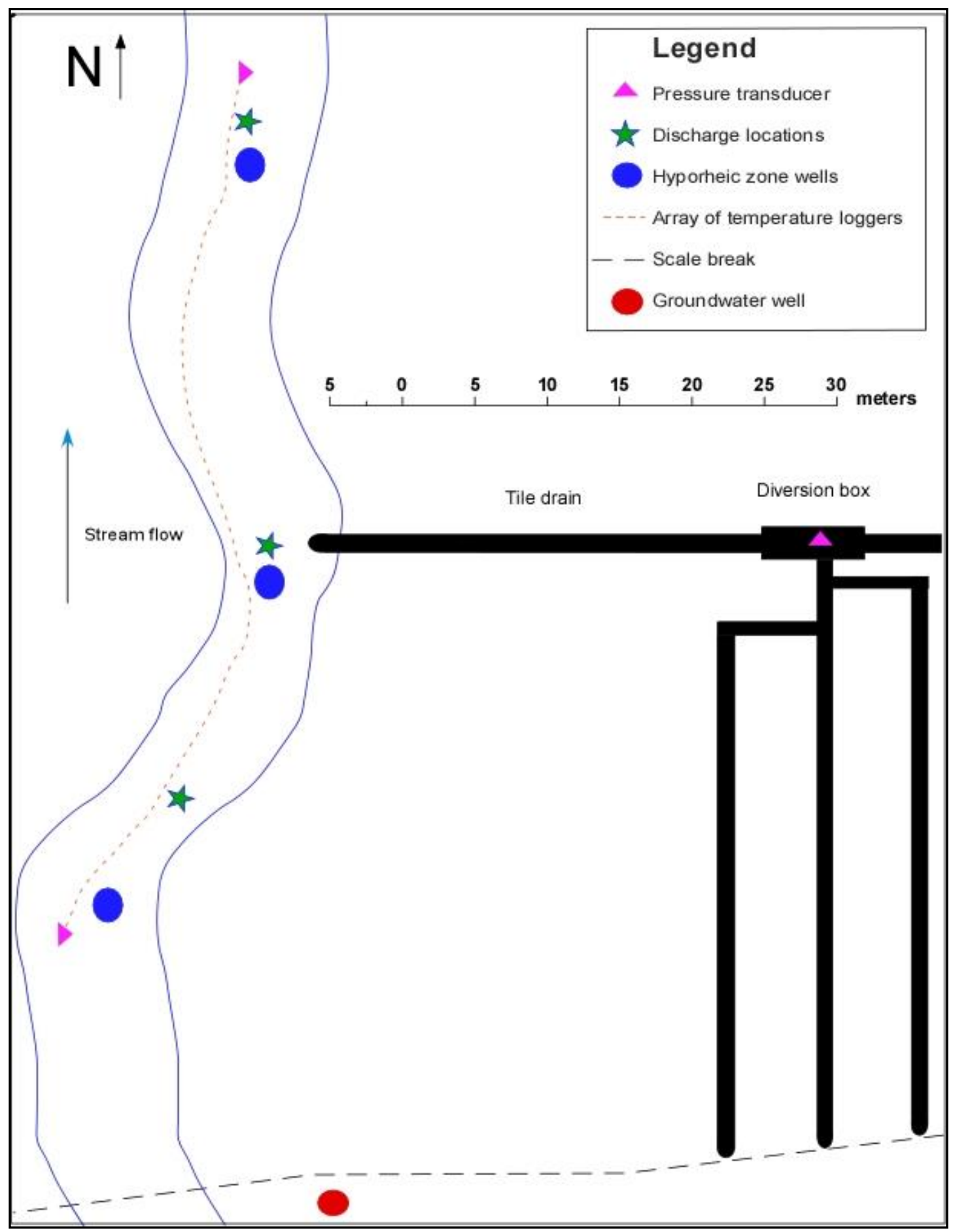

Figure 5. Schematic of study site and locations of data collection. The dashed black line indicates a break in scale as the groundwater well is over $1.2 \mathrm{~km}$ southeast of the most upstream hyporheic zone well. 


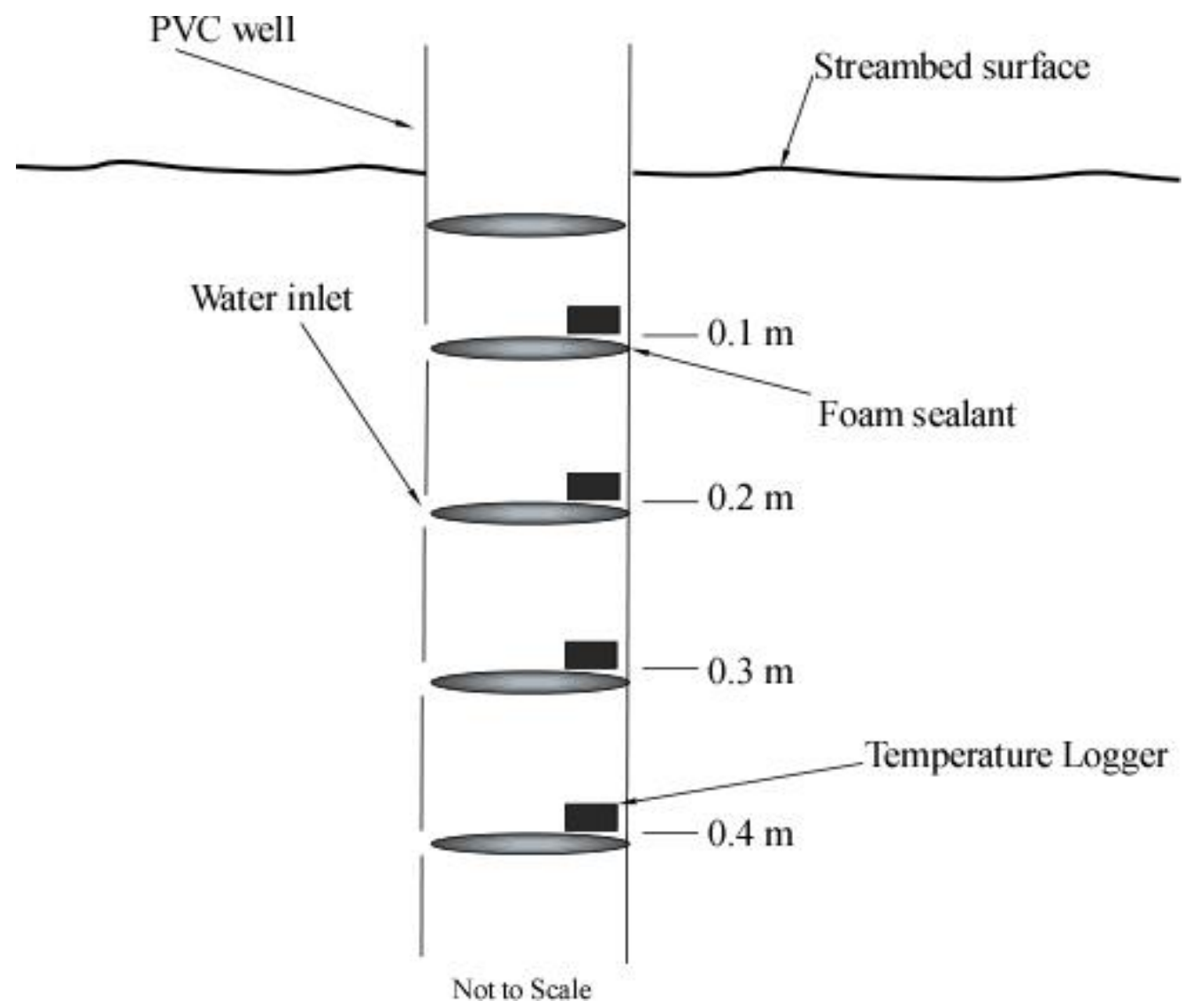

Figure 6. Schematic of hyporheic zone wells

\section{Data Analysis}

The discharge data were analyzed for relationships between tile-flow events and non-tile-flow events. The mean $(\mu)$ discharges for the upstream $(\mathrm{Qu})$ and downstream $(\mathrm{Qd})$ locations were calculated for both tile-flow and non-tile-flow events. The discharge data displayed as box and whisker plots depicting the mean and the data within the confidence intervals (95\%) for each tile-flow conditions (McGrew and Monroe, 2009). The $\mu_{\mathrm{D}} \neq \mu_{\mathrm{U}}$ is the alternative hypothesis, while $\alpha=0.05$ to better minimize the sampling error of the discharge measurements (McGrew and Monroe, 2009). The calculated Z-scores standardized the data to check for any outliers; if the z-scores are larger than \pm 2.0 , reject 
the null hypothesis (McGrew and Monroe, 2009). Then the upstream and downstream discharges checked for any spatial correlation using a scatterplot to understand the relationship between $\mathrm{Qu}$ and $\mathrm{Qd}$ with and without the effect of the tile-drain input. The linear relationship implied that the usage of a bivariate regression model to see if the downstream discharge could properly predict the upstream discharge for the entire dataset and each tile-flow scenario. The slope of the regression line and the y-intercept of each scenario were then checked for significance with a $p<0.05$. The slope indicates the influence of $\mathrm{Qd}$ on predicting $\mathrm{Qu}$, while the intercept of the regression analysis signifies whether the regression starts at zero or not. Changes in slope between the various tile-flow conditions indicate a hydrologic change. Next, a paired t-test analyzed the upstream versus the downstream discharge for a statistically significant difference for each tile flow scenario. The means of the downstream discharge minus upstream discharge for tile-flow and non-tile-flow were compared for a significant difference using a nonparametric test (Independent Means Whitney U test for limited sample size, $n=26$ ) to see any hydrologic effect of the tile-drain on the stream discharge. (McGrew and Monroe, 2009)

A heat map created to understand the temporal and spatial variation seen throughout the streambed array. Inconsistencies in temperature across the array were analyzed for additional inputs, such as point source upwelling or anthropogenic inputs, along the streambed; paired t-tests were conducted between adjacent loggers throughout the array. Alterations to the array downstream of the tile-drain will determine if the tile-water leaves an acute shock to the overall stream temperature after large precipitation events and/or during baseflow (Bastola, 2011). 
With the heat map to visualize thermal alterations on the stream temperature, a mixing model was introduced to calculate an equilibrium temperature between the tilewater and the stream. Equation 1 is a mass balance equation where two reservoirs are compared thermally at the respective mass.

$$
\mathrm{M}_{\mathrm{s}} \mathrm{C}_{\mathrm{s}}\left(\mathrm{T}-\mathrm{T}_{\mathrm{s}}\right)=-\mathrm{M}_{\mathrm{t}} \mathrm{C}_{\mathrm{t}}\left(\mathrm{T}-\mathrm{T}_{\mathrm{t}}\right)
$$

Equation 1. Thermal mass balance equation.

$$
\mathrm{T}=\left(\mathrm{Q}_{\mathrm{s}} \mathrm{T}_{\mathrm{s}}+\mathrm{Q}_{\mathrm{t}}+\mathrm{T}_{\mathrm{t}}\right) /\left(\mathrm{Q}_{\mathrm{s}}+\mathrm{Q}_{\mathrm{t}}\right)
$$

Equation 2. Algebraic alteration to find theoretical mixing temperature.

$$
\mathrm{Q}_{\mathrm{t}}=\mathrm{Q}_{\mathrm{s}}\left(\mathrm{T}_{\mathrm{s}}-\mathrm{T}\right) /\left(\mathrm{T}-\mathrm{T}_{\mathrm{t}}\right)
$$

Equation 3. Algebraic alteration to find theoretical tile-discharge.

Equation 2 is the algebraic alteration of equation (1) used to quantify the equilibrium temperature needed to see any observed temperature alteration by the tile-water on the stream's thermal signature using stream discharge $\left(\mathrm{Q}_{\mathrm{s}}\right)$, tile-drain discharge $\left(\mathrm{Q}_{\mathrm{t}}\right)$, stream temperature $\left(T_{s}\right)$, and stream temperature $\left(T_{t}\right)$. The equation was limited by tile-discharge data. The tile flow was only recorded on four field days in early to mid-July pre-diversion; on two other occasions, the stream stage was above the tile outflow. Then equation 3 was used to calculate the theoretical volume flux needed to see a temperature difference of $0.28^{\circ} \mathrm{C}$ (double the thermal resolution of the data loggers) at the observed temperatures and stream discharge.

The thermal effect of the groundwater was analyzed by looking at the thermal regime in the hyporheic zone. A thermal envelope made with the coolest and warmest 
temperatures at each depth and location to set the boundaries of the thermal regime were analyzed by shape. The convergence of the envelopes concludes that within the hyporheic zone the groundwater and stream water mix (Arnold and Allen, 1996; Rohan et al., 1998; Silliman and Booth, 1993; Lapham, 1993; Baskaran et al., 2009; Keery et al., 2007, Oware, 2010). The three well locations were then analyzed for spatial variation both at depth and at the streambed. The thermal envelopes compliment the heat map data in understanding the effects of groundwater on T3. 


\section{CHAPTER III}

\section{RESULTS}

\section{Stream Discharge}

The stream, T3, was observed in two capacities. First, stream discharge was measured at the upstream $(\mathrm{Qu})$ and downstream $(\mathrm{Qd})$ locations of the temperature array. The basic descriptive statistics calculated for four separate datasets: upstream no tile-flow, upstream tile-flow, downstream no tile-flow, and downstream tile-flow (Table 1). The mean discharge for each location increases from no tile-flow to tile-flow (Figure 7). A correlation analysis found a strong linear relationship between downstream and upstream discharge $r(26)=0.865, \mathrm{p}<0.01$ (Figure 8). Data points were then standardized using $\mathrm{z}$ scores to look for outliers. Case $2(\mathrm{z}=3.2)$ was determined an outlier for both the upstream and downstream Q measurements. A residual analysis was then conducted on the remaining data points and the results concluded that case $27(\mathrm{z}>3.8)$ was also an outlier. The correlation improved without the two aforementioned outliers, $r(24)=0.933, p<0.01$. A regression test was then used for tile flow $(y=0.1+0.97 x)$ and non-tile flow $(y=85 x)$ conditions to see if downstream discharge can predict upstream discharge. The tile-flow regression analysis shows a statistically significant slope and intercept, while only the slope found significant during non-tile flow periods (Table 2). A test of significance performed by using paired t-tests for both tile flow conditions; the results showed no significant difference between upstream and downstream discharge for non-tile flow, and 
a difference for tile-flow conditions (Table 3). The shift in intercept from the 1:1 line for the tile-flow conditions indicates an increase in upstream discharge when compared to downstream discharge (Figure 9). Non-tile flow conditions show more variance in the predicted values versus the actual discharges (Figure 10). The mean difference in upstream discharge minus downstream discharge (Qu-Qd) for both tile-drain conditions considered for a statistical difference. During tile flow conditions, the discharge difference increases (mean $=0.09 \&$ standard deviation $=0.02)$ compared to non-tile flow conditions (mean=0.01 $\&$ standard deviation=0.02) (Figure 11). The significant difference for difference in discharge, $\mathrm{p}=0.00$, indicates that upstream discharge is greater than downstream discharge when the tile-drain is flowing to T3.

TABLE 1. DESCRIPTIVE STATISTICS FOR DISCHARGE DATA FOR BOTH TILEFLOW CONDITIONS

\begin{tabular}{cccccc}
\hline & Tile & Sample & & Standard & \\
$\mathbf{Q}$ & Flow & Size & Mean & Deviation & Outliers \\
\hline $\mathrm{Qu}$ & No & 20 & .07713 & .04386 & - \\
& Yes & 8 & .36115 & .18748 & 2 \\
& No & 20 & .07016 & .04453 & - \\
\hline
\end{tabular}



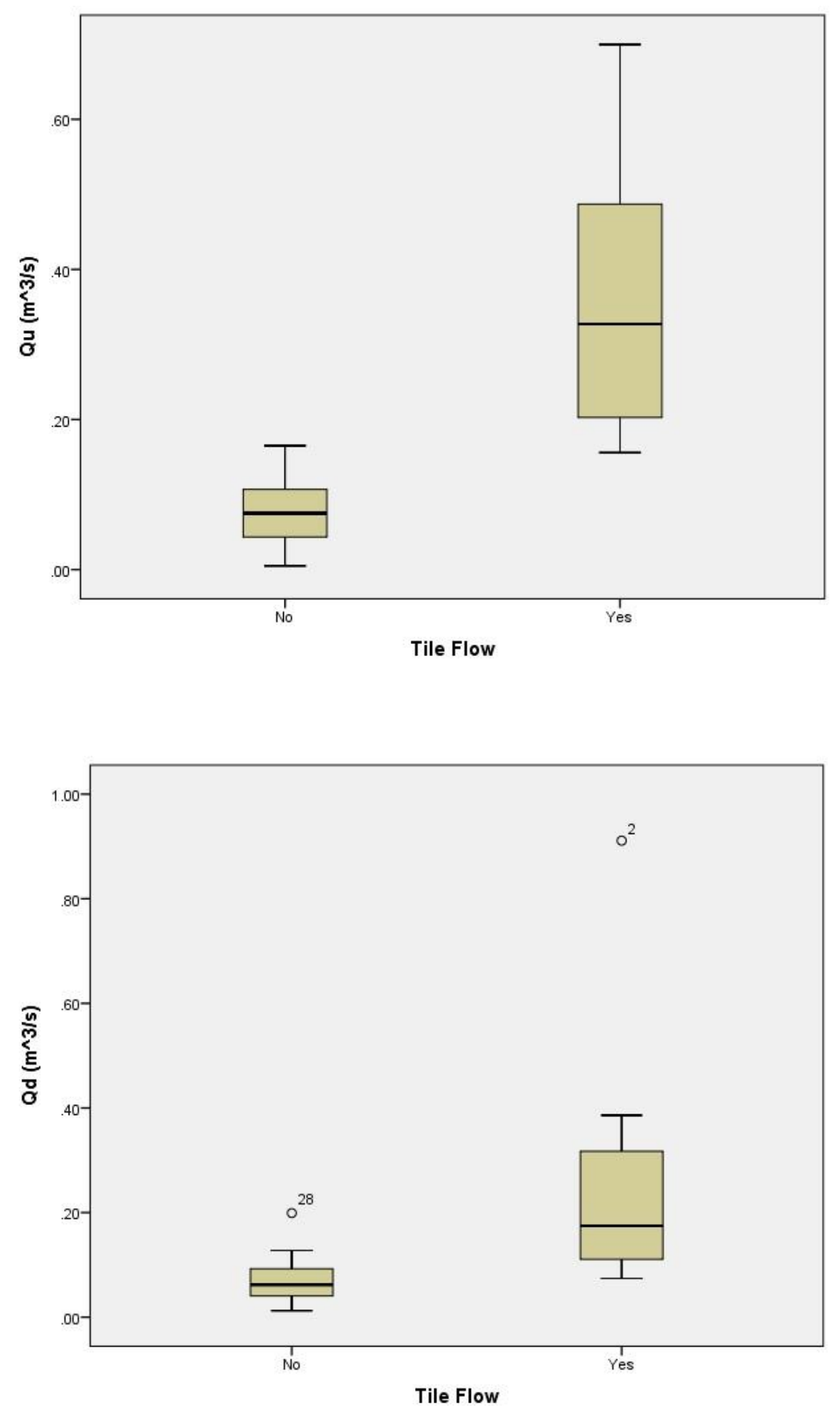

Figure 7. Comparison of stream discharge in the absence or presence of tile flow at upstream and downstream locations. 


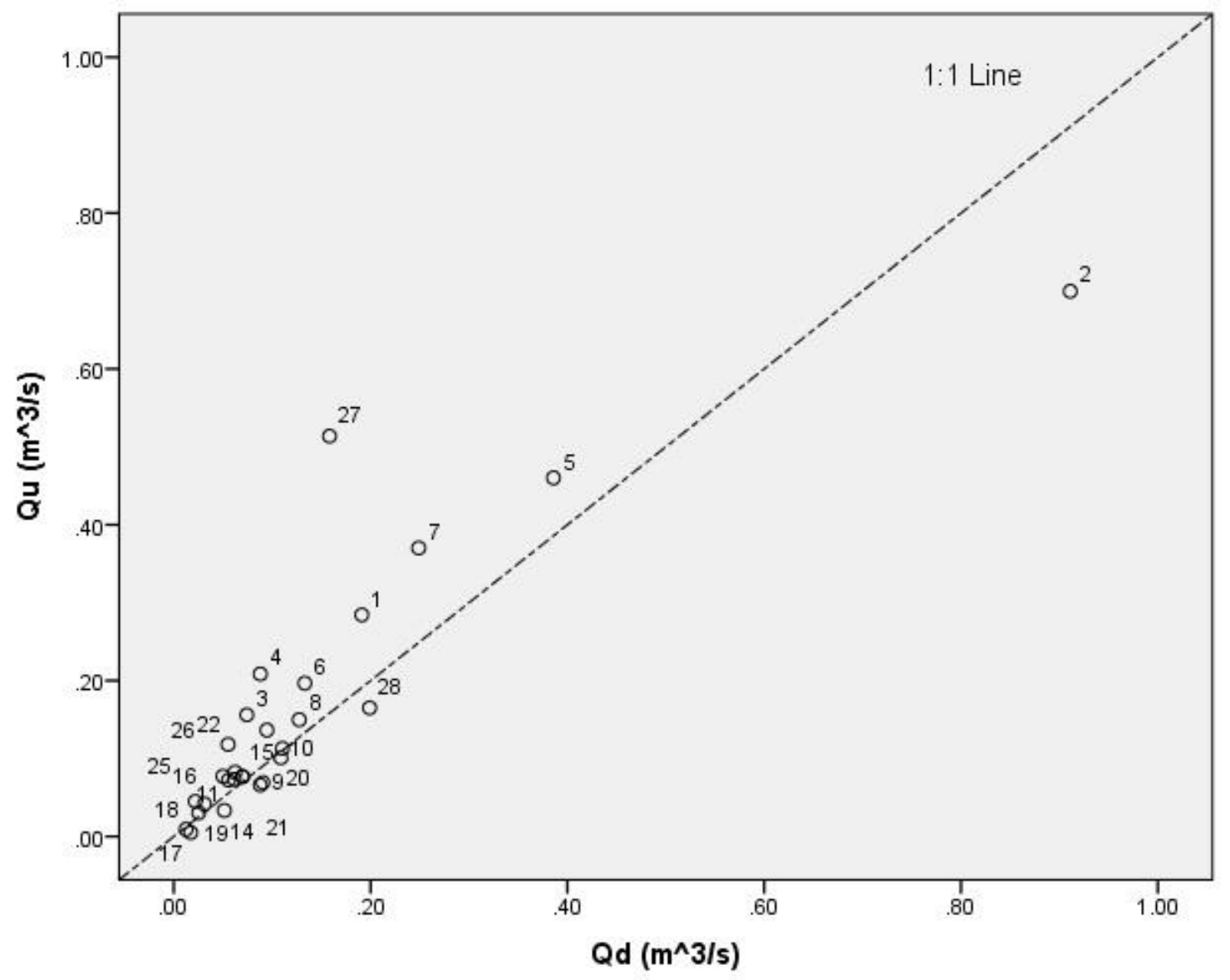

Figure 8. Correlation between the upstream and downstream discharge. A linear trend seems evident from the graph. Data point 27 is determined a residual outlier and data point 2 is an influential point skewing the dataset. 
TABLE 2. REGRESSION STATISTICS FOR TILE FLOW AND NON-TILE FLOW MODELS

\begin{tabular}{ccccccc}
\hline Model & $\mathbf{R}^{2}$ & $\begin{array}{c}\text { Significance } \\
\text { (2-tailed) }\end{array}$ & Slope & $\begin{array}{c}\text { Significance } \\
\text { (2-tailed) }\end{array}$ & $\begin{array}{c}\text { Intercept } \\
\left(\mathbf{m}^{\mathbf{3}} / \mathbf{s}\right)\end{array}$ & $\begin{array}{c}\text { Significance } \\
\text { (2-tailed) }\end{array}$ \\
\hline Tile Flow & .958 & .001 & .973 & .001 & .097 & .011 \\
Non-tile & .744 & .000 & .849 & .000 & .018 & .087 \\
Flow & & & & & & \\
\hline
\end{tabular}

TABLE 3. PAIRED T-TEST RESULTS OF SIGNIFICANCE BETWEEN UPSTREAM AND DOWNSTREAM DISCHARGE FOR TILE FLOW AND NON-TILE FLOW MODELS

\begin{tabular}{cccc}
\hline Model & T & DF & Significance (2-tailed) \\
\hline Tile Flow & 9.404 & 5 & .000 \\
Non-tile Flow & 1.344 & 19 & .195 \\
\hline
\end{tabular}




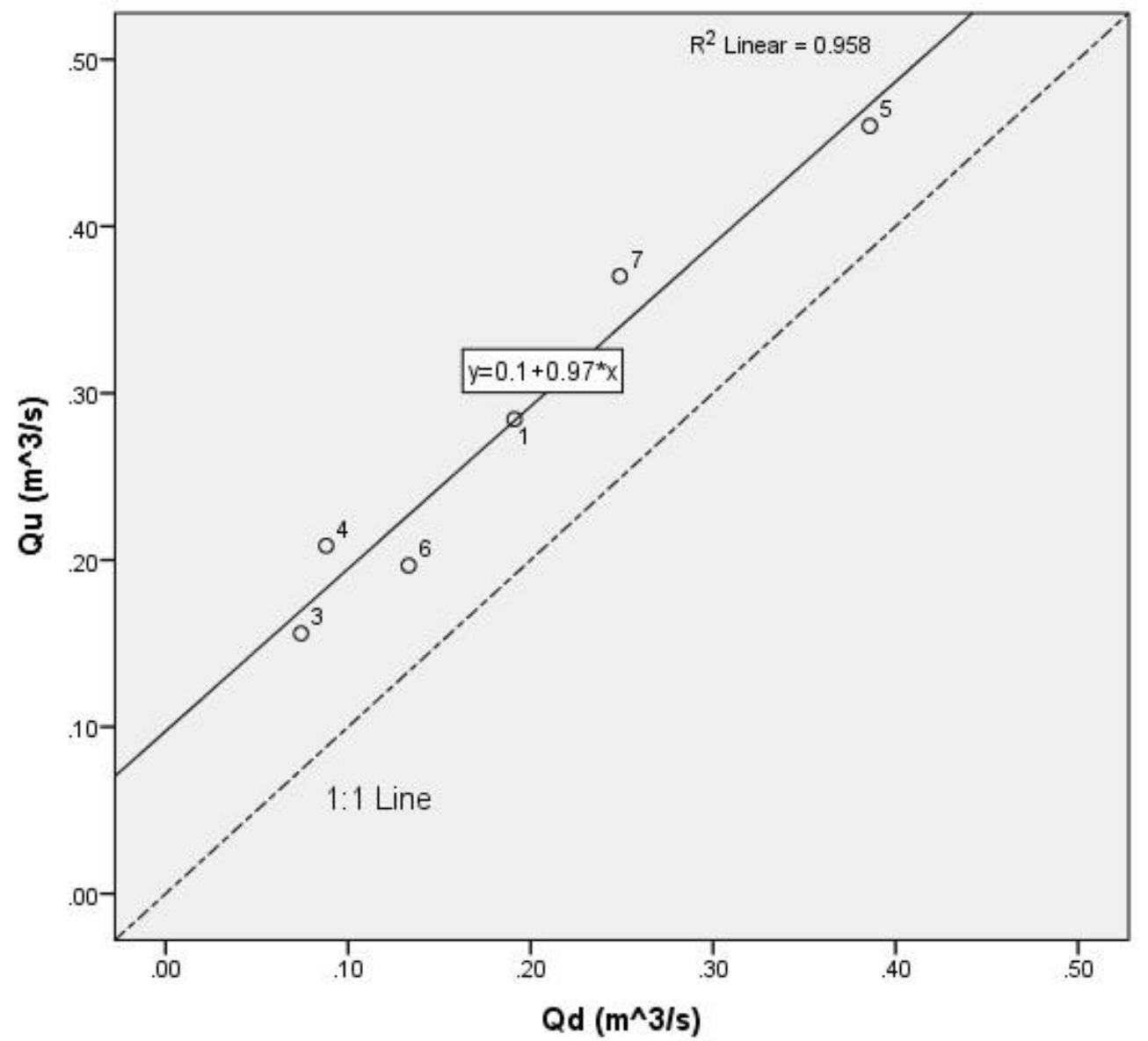

Figure 9. Linear regression of downstream discharge predicting upstream discharge during tile flow conditions. 


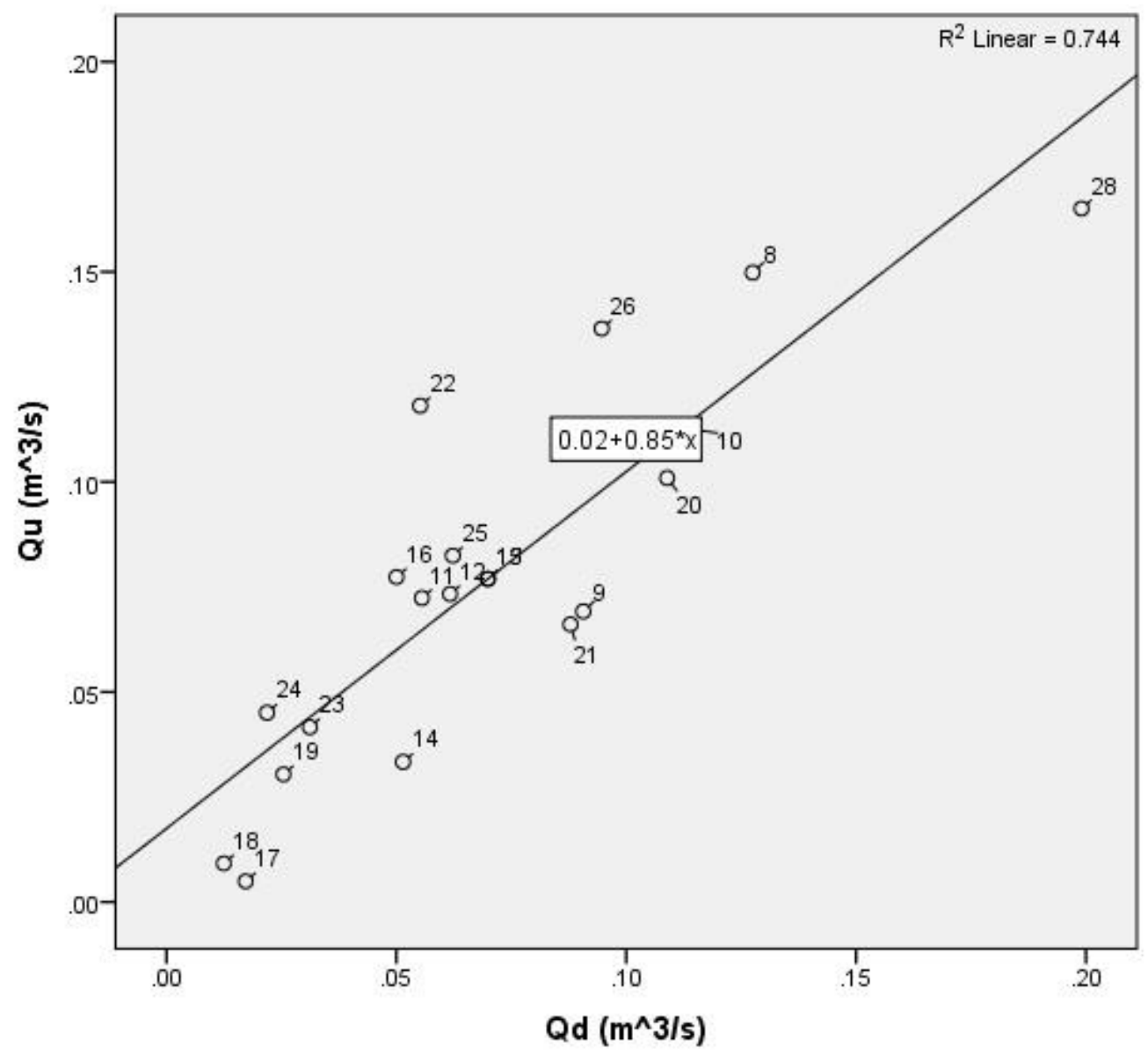

Figure 10. Linear regression of downstream discharge predicting upstream discharge during non-tile flow conditions. 


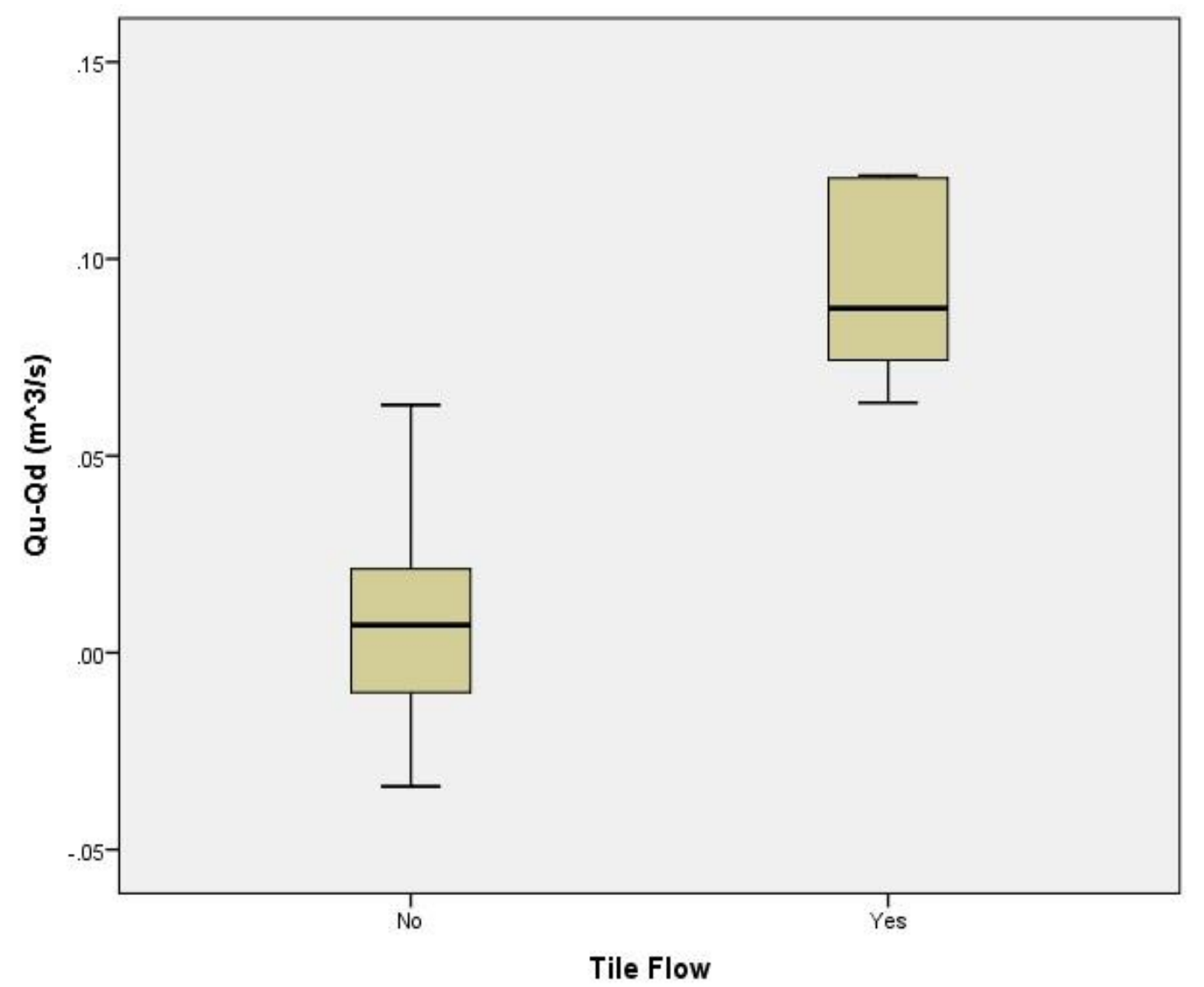

Figure 11. Comparison of the difference in stream discharge between the upstream $\left(Q_{u}\right)$ and the downstream $\left(Q_{d}\right)$ dependent on tile flow. The difference increased from a median of 0.00 to $0.09 \mathrm{~m}^{3} / \mathrm{s}$ in the presence of tile flow.

\section{Stream Temperature}

The array of streambed temperature loggers was analyzed for both a temporal and spatial variation. The heat map (Figure 12) displays average daily data from December 2014- October 2015. Temporally, the data displays the seasonal trends synonymous with most streams, as solar radiation drives the thermal energy in the system. Spatially, the array displayed horizontal consistency throughout the 60-meter stretch. The exception is one anomaly spotted in mid-June over a 4-6-meter stretch just upstream of the tile-drain (Figure 12). With the overall consistency of temperature within the dataset, each location was 
analyzed for a difference in means from location zero. Each location was found to be statistically the same with the exception of the temperature anomaly previously mentioned.

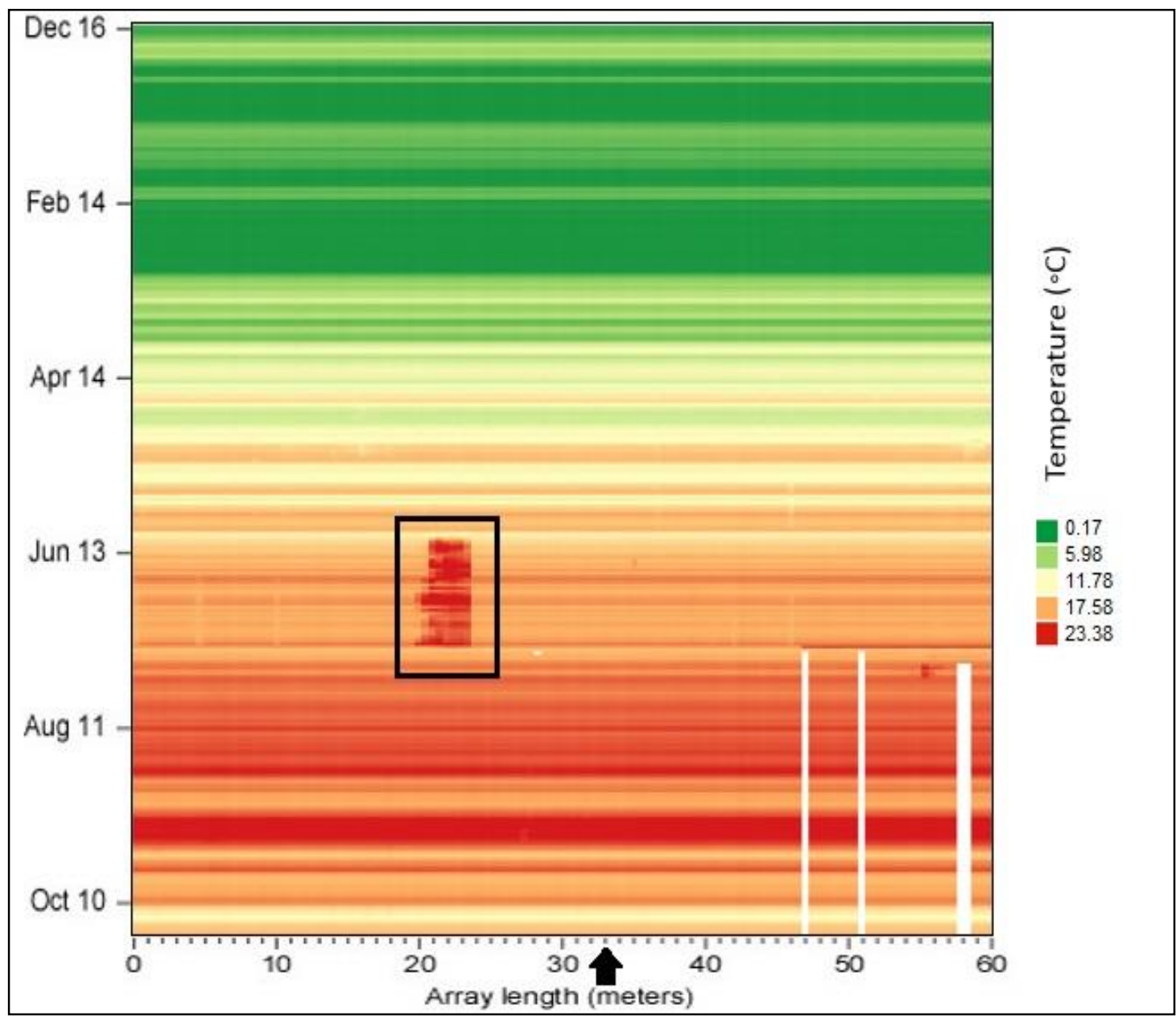

Figure 12. Heat map depicted by set color ranges along streambed. The image depicts loggers spatially ( $x$-axis) and temporally ( $y$-axis). The white space shown indicates when a few loggers stopped recording data as the batteries expired. The black arrow indicates the location of the tile-drain along the array, while the black box indicates a temperature anomaly. 


\section{Thermal Impact of Tile-Water}

The tile-water displayed a thermal signature with less diurnal variation than the stream temperature recorded (Figure 13). The latter seems to follow the air temperature more closely. The tile-drain temperature was dependent on whether water was in the diversion box or not. As water flowed pre-diversion (July 17), the temperature recorded is between the stream and groundwater temperatures. The difference between stream and tilewater temperature is three degrees Centigrade when flowing out to the stream during the summer of 2015. After diversion, the water is cut off to the stream and redirected into the riparian zone. The diversion along with the lack of significant precipitation over late July and August led to a decrease in water volume in the tile diversion box starting in late August. After the tile was diverted, the tile temperature displays a more similar signature to that of the stream as water did not flow out of the diversion control box until a large precipitation event in late November allowed the tile to flow again and the tile-water temperature to stabilize (Figure 13). The stagnant water temperature then mimicked the larger diurnal variations of the stream driven by air temperature and solar radiation of the diversion box 


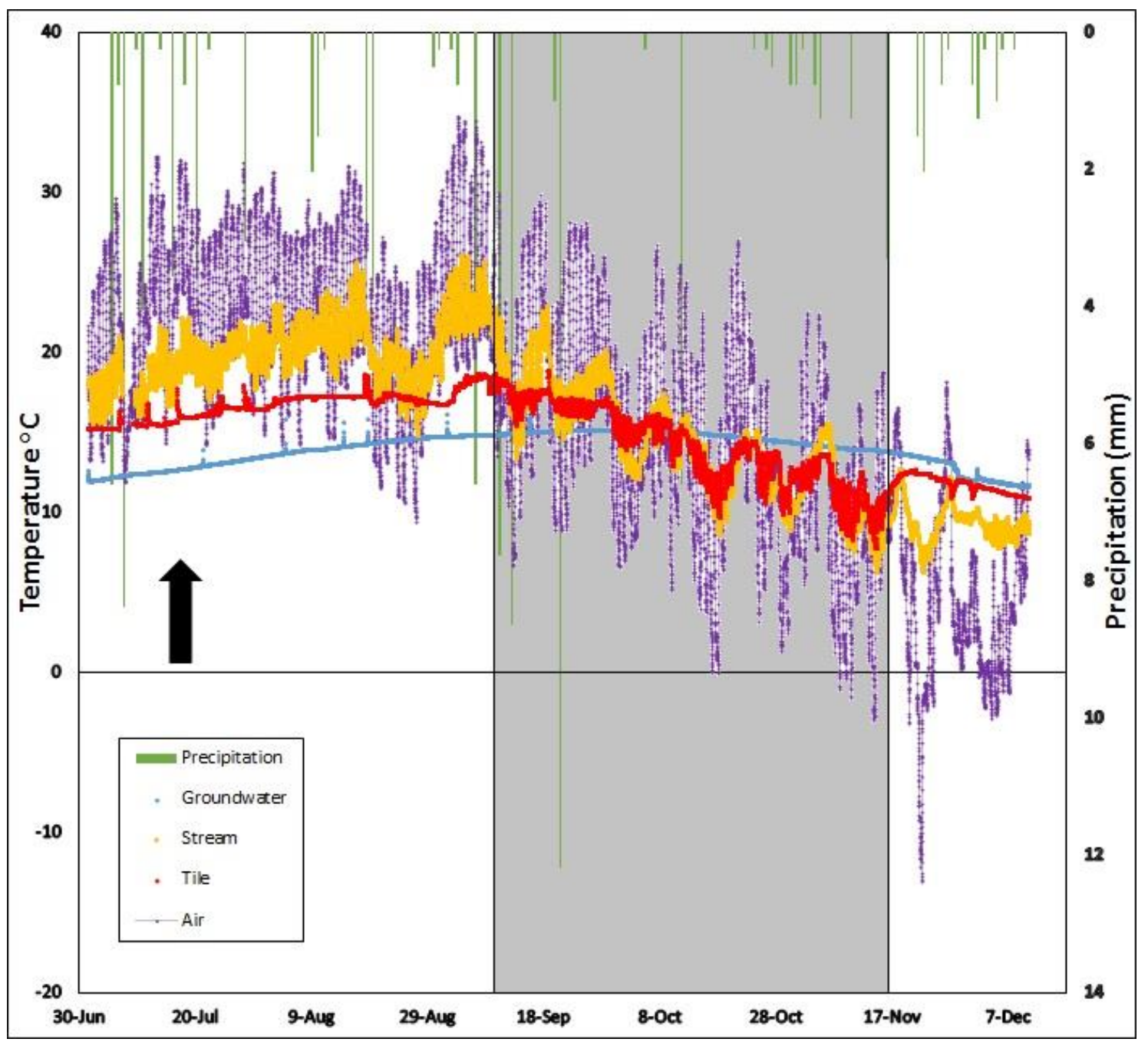

Figure 13. Time series compilation of precipitation, air temperature, stream temperature, groundwater temperature, and tile-drain temperature. Data was collected from July 1-December 10, 2015. Shaded area indicates no tile flow and black arrow shows the tile diversion event.

With the difference in temperature between the tile-water and streambed evident, mixing model equation 2 found the equilibrium temperatures for the four days when tile discharge was measured; the model outputs were all within the thermal resolution of the loggers $\left(0.14^{\circ} \mathrm{C}\right)$ with the largest difference in equilibrium temperature to only the stream temperature of $0.10^{\circ} \mathrm{C}$. With no thermal signature from the tile-water visible throughout the stream array spatially or temporally (Figure 12), the tile-drain temperature is 
insignificant on the stream at the volume flux observed during the study period (0.001$0.002 \mathrm{~m}^{3} / \mathrm{s}$ ). Equation 3 was then used for all four situations analyzed to find a hypothetical tile discharge that would decrease the stream temperature by $0.28^{\circ} \mathrm{C}$ for an acute thermal shock. The discharge of the tile-drain increased a full order of magnitude to see the tilewater temperature decrease the stream temperature by at least double the logger the resolution. Discharge of the tile ranged from 0.007 to $0.019 \mathrm{~m}^{3} / \mathrm{s}$ in this scenario.

\section{Thermal Impact of Groundwater}

Temperature profiles were recorded at all 0.1, 0.2, 0.3, and 0.4 meter depths, but only two different depths, 0.2 and 0.4 meters, at three different locations beneath the streambed were analyzed with the other locations having incomplete or no transferrable data. An ANOVA was taken of the six sampled signatures and a variation was noticed at in respect to both locations in the array and depth into the hyporheic zone at each depth. A t-test $(\alpha=0.05)$ was taken for each locale (Upstream, Middle, and Downstream) at 0.2 and $0.4 \mathrm{~m}$ depth; each of the three well locations found a statistically different relationship between the two depths. Then a t-test $(\alpha=0.05)$ was taken at each depth to compare the three localities. Each well location was found to be statistically different between each

other. There was a larger difference between the temperatures of the middle well and either the temperatures of the upstream or downstream wells than between the upstream versus the downstream. Thermal envelopes (Figure 14) were created to visualize the warmest and coolest temperatures for each location. The streambed $(0.0 \mathrm{~m})$ and groundwater $(1.0 \mathrm{~m})$ temperatures were used to create the envelopes with the subsequent well data. The cooler temperatures recorded are vertically consistent for each locality, while the warmest temperatures show a difference below $0.2 \mathrm{~m}$ depth. The middle well, closest to the tile, 
showed a $2-3^{\circ} \mathrm{C}$ lower temperature compared to that of either the upstream or downstream well.

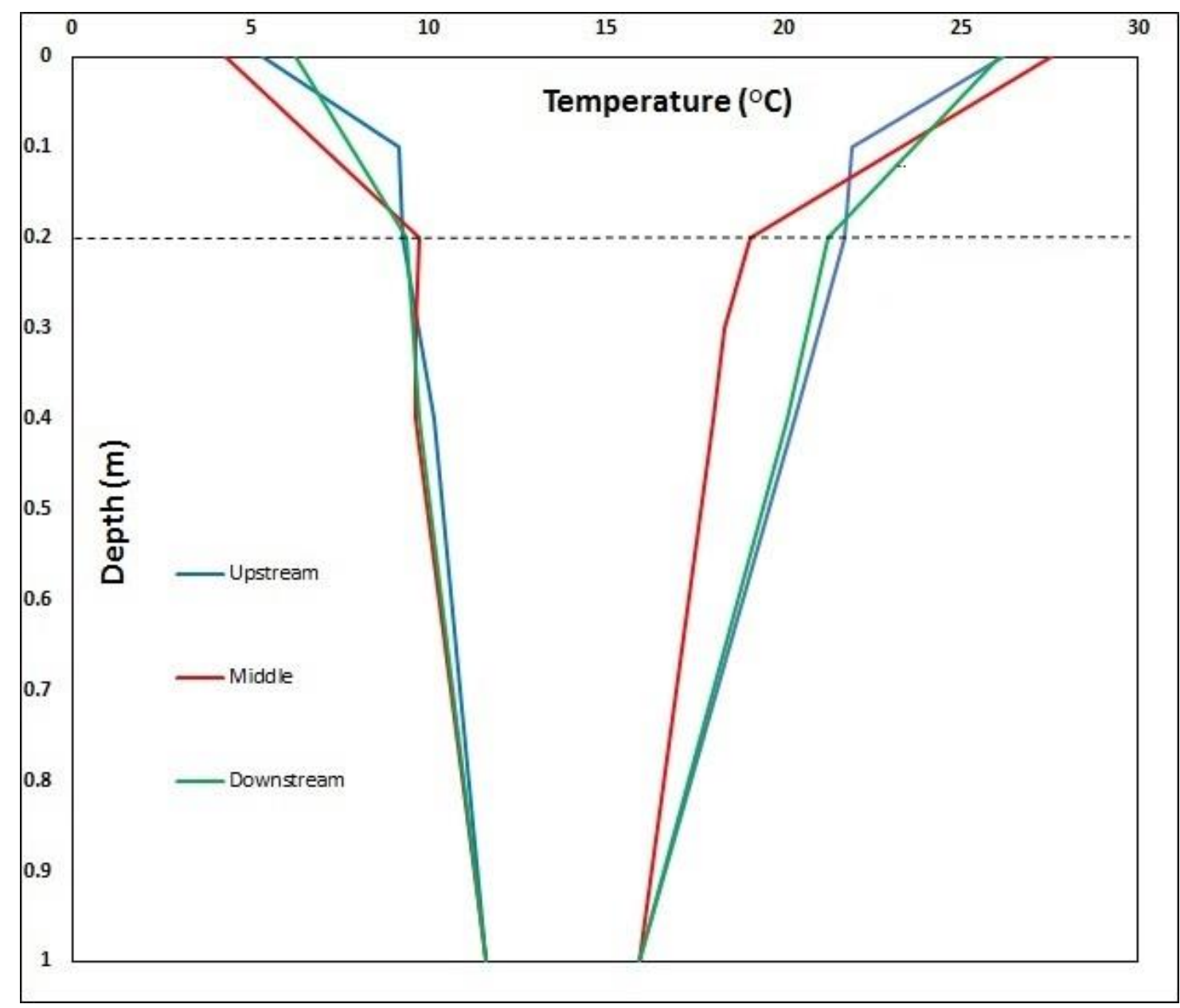

Figure 14. Thermal envelopes show the coldest and warmest temperatures for the three hyporheic wells. Data was taken at each depth: 0.0, 0.1, 0.2, 0.3, and 0.4 meters, and the groundwater temperature used at 1.0 meter beneath the streambed. 


\section{CHAPTER IV}

\section{DISCUSSION}

\section{Hydrologic Influence}

The downstream and upstream discharge variance observed between tile-flow and non-tile-flow events is visible with a change in slope and intercept in the regression analysis (Figures 9\&10) and a significant difference in means for the tile-flow events, but insignificant for the non-tile flow conditions. Neither show a true 1:1 relationship between upstream and downstream discharge signifying some variance in discharge spatially. Figure 7 shows the mean discharge for both locations in the stream increases during tile-flow; the higher stream discharge corresponds with higher stage events of the summer. The difference in means (Figure 11) would indicate the upstream discharge increases more than the downstream discharge when the tile is flowing. This is counterintuitive as if one adds another source to the reservoir, and then the downstream discharge should be greater than the upstream discharge.

The opposite effect could be due to several reasons. All the tile flow events correspond with storm flow or baseflow events in the stream before diversion. Tile flow may have a more added impact if flowing into the stream during low-flow conditions in T3 that were visible in late August and September (Cassie et al., 2014). The latter thought, however, is limited by the amount of precipitation to recharge the tile-drain 
to flow from the upgradient farm to T3 (Skaggs et al., 1994). A mistake made in measuring stream discharge could also account for results. The USGS velocity-area method recommends at least 15 to 20 velocity measurements per cross-sectional area; this data was collected at 10-12 equidistant locations across T3 throughout the study period. This method may not truly account for the streamflow appropriately at any of the locations measured. Another possible explanation for the upstream discharge to be greater than the downstream discharge is the role of the underlying geology. The study site loses over the reach (Figure 11) and groundwater seems to be flowing across the stream from SE to NW. Therefore, the stream is not a groundwater divide as previously thought; instead the role of a sand and gravel layer may not allow for as much groundwater to recharge the stream in the downstream section as the upstream.

\section{Thermal Impact of Tile-Water}

The thermal signature of the tile-water is influenced by several factors. The temperature of the tile-drain reflects solar radiation, air temperature, the movement of water flow, and transfer of heat from the tile diversion box. The time series shows no diurnal cycles, but seasonal variation is evident (Figure 13). The lack of diurnal variation indicates the tile-water temperature is insulated from external factors of solar radiation by the ground. The tile-water temperature follows the same trend as the groundwater, yet warmer than the groundwater temperature due to the closer proximity to the surface (Figure 13). The thermal spikes visible are short-scale temporally and adhere to precipitation inflow of water flowing into the still-curing diversion box. The groundwater does not show any corresponding spikes from precipitation events. 
Diverting the tile-water into the riparian zone in mid-July altered the observed thermal signature. Pre-diversion, the tile temperature is muted in comparison to the stream and thus the air temperature (Figure 13). Post-diversion, the tile-water does not flow out to the stream either stagnating in diversion box or pushing out to the riparian zone. The tilewater temperature closely mimics the stream temperature post-diversion (Figure 13). With no water flowing through the tile, the water in the box became stagnant and began to equilibrate to the air temperature. The diversion box then transferred heat to the tile-water moving the signature to assimilate with weather patterns. When water flows through the tile again in late November, air temperature no longer drives the thermal regime of the tilewater signature. The short-term and long-term surface controls on the tile-water temperature are visible.

Diurnal and seasonal cycles are present in the record throughout the stream array with little spatial difference (Figure 12). The stream is thermally controlled by solar radiation and air temperature (Loheide and Gorelick, 2006), and the homogenous nature of the streambed array suggests other inputs are limited in impact (Figure 12). The diurnal variations seen in T3 (Figure 13) and the discharge measurements taken (Figure 11) support the idea of a losing stretch. A losing stretch is more susceptible to changes in temperature than a gaining stream without a steady input of more thermally consistent groundwater (Anderson, 2005). Stream temperature is also most susceptible to changes during low-flow events (Baskaran et al., 2009); Figure 11 displays the low-flow conditions in late summer with low precipitation that would show tile-influence on stream temperatures. These conditions are post-diversion and coincides with the lack of tile flow (Figure 13). 
The insignificant thermal effect of the tile-drain on stream temperatures is a product of the disparity between stream temperature and that of the tile is not great enough $\left(3-5^{\circ} \mathrm{C}\right)$ to see the any alteration on the streambed at the current discharge rates. Any change greater than the resolution of the loggers could be missed as thermal energy dissipates and equilibrates with the stream through mixing. The mixing model used shows that any thermal alteration of the tile-water is limited by the disparity in discharge between the stream and the tile-drain. The more likely scenario is not the temperature difference of the tile but mass difference between the stream and the tile-drain. The tile-drain has a discharge two-orders of magnitude less than the stream and a drainage area of 26.3 hectare or $3 \%$ of the stream's total drainage area (Figure 4). The ratio of tile discharge to stream discharge is 0.01 and this discrepancy in discharge rates is enough for the stream temperature to overwhelm the tile-water despite the temperature difference. The lack of a consistent tileflow during all conditions is also a factor to consider as the tile-drain discharge was only recorded during high-flow conditions in T3 when discharge values were above $0.08 \mathrm{~m}^{3} / \mathrm{s}$. A theoretical tile-discharge is needed to see any thermal alteration on streambed temperatures of at least $0.28^{\circ} \mathrm{C}$; the possibility of this theoretical tile-discharge is highly improbable without increasing the size of the tile or its drainage area. The other assumption has to be stated that as the tile-drain fills up with more water flowing to the stream, T3 will also inevitably increase its discharge up to bankfull conditions are reached. All the evidence supports the thought that the tile-drain has no thermal effect on the stream during baseflow or storm flow conditions at the resolution of the loggers used in this study. 


\section{Thermal Impact of Groundwater}

Although the tile-drain has limited thermal effect on the stream, the thermal impact of the groundwater on the stream was not yet understood. Hyporheic zone temperatures are moderated by the influence of mixing between groundwater and surface water beneath the streambed (Dogwiler and Wicks, 2006; Bastola, 2011; Beach, 2008) and indicate the control or driver of the thermal energy in the system (Keery et al., 2007). Influence from surface water reflect diurnal and seasonal trends in temperature, while any mixing from groundwater will dampen or mute the thermal variation in the hyporheic zone with a delayed response (Stonestrom and Constantz, 2004; Loheide and Gorelick, 2006). The spatial consistency of the streambed (Figure 12) shows temperature in equilibrium suggesting a diffused groundwater system with no point sources; the major flow path in the hyporheic zone beneath T3 is horizontal. All hyporheic loggers displayed diurnal variation similar to that of the streambed array.

Thermal envelopes suggest the upwelling or downwelling nature of the flow paths beneath the stream (Keery et al, 2007; Bastola, 2011; Lapham, 1989) with the coolest and warmest temperatures displayed at various depths. The thermal envelopes for the three wells conclude that the thermal regime of the hyporheic zone is a mixed system (Figure 14). The vertical consistency of the envelopes suggests that groundwater upwelling is the

dominant driver of thermal energy in the system during the winter; upwelling groundwater as a point source would show a spatial variation of the streambed temperatures (Anderson, 2005). Upwelling in winter keeps the stream away from frozen conditions (Cassie et al., 2014). During low-flow conditions in September when the warmest temperatures are observed, the top 0.2 meters below the streambed (Figure 14) is driven by the losing nature 
of the stream. As stream water enters the hyporheic zone, the flow paths are referred to as hyporheic exchange (Burkholder et al., 2008; Wondzell, 2011). The hyporheic exchange transfer thermal energy to the water of the hyporheic zone through conduction with the streambed (Burkholder et al., 2008). Beneath $0.2 \mathrm{~m}$, the envelopes suggest influence from the groundwater with a more consistent thermal gradient observed. The thermal regime is driven by the mixing of deeper hyporheic flow paths (Contant Jr., 2004; Cassie et al., 2014) and upwelling groundwater (Burkholder et al., 2008). The temperature variation at depth are the result of hyporheic exchange differing from stream temperatures throughout diurnal cycles because of buffering of the streambed (Burkholder et al., 2008). Ultimately, the stream's ability to distribute its thermal energy (Cassie et al., 2014; Beach, 2008; Stonestrom and Constantz, 2003) to the underlying hyporheic regulates the temperatures observed at depth and is muted by a low flux of groundwater recharge on the stream (Contant Jr., 2004). The thermal envelopes (Figure 14) and the heat map (Figure 12) compliment the thought that the streambed is in equilibrium with the thermal energy with a zone of mixing below the streambed up to 0.4-meters depth.

The thermal envelopes (Figure 14) and difference in discharge measurements in T3 (Figure 11) support the idea of downwelling. Temporally, the three hyporheic wells display consistent cold temperatures with little variation (Figure 14). However once the stream temperature varies more with air temperature following winter, a spatial variation is visible between the three well locations. The middle well is $2-3^{\circ} \mathrm{C}$ cooler than the upstream and downstream well during the spring through the early autumn. This well is closest to the tile input (Figure 5), but with no tile flow in September during the highest recorded temperatures there are few possible explanations for the spatial variation observed 
over the 60-meter stretch. Variation in solar radiation for the middle well compared to other locations is possible with a large tree lying near the west bank that could shade the water (Figure 4). Longwave radiation would not be able to warm the hyporheic near the middle well as effectively as the remainder of the array (Loheide and Gorelick, 2006). The data do not support this though with the warmest streambed temperatures also recorded at the middle well (Figure 14) and no variation in the stream array (Figure 12). Shade would limit the recorded temperature at both depth and at the surface.

Without solar radiation as a factor, an area of increased upwelling from the groundwater is possible to reduce the observed temperatures in the middle well (Figure 2). The streambed temperatures displayed in Figure 12 suggest a homogeneous system. The observed temperatures then do not suggest any point source upwelling into the stream but a diffuse pattern; an area of groundwater upwelling would be visible with cooler streambed temperatures near the middle well. A more likely explanation is streambed heterogeneities within the Wedron Group inhibiting large amounts of groundwater upwelling from entering the hyporheic and from steadying both the temperature signals of the hyporheic and the stream. Spatial heterogeneities are likely the cause of the temperature difference (Wondzell, 2011). A varied hydraulic conductivity would decrease the downwelling water in this area and allow for more upwelling to influence the hyporheic zone near the middle well (Burkholder et al., 2011). In low-gradient streams, like T3, head loss along longitudinal profiles are compressed to steps (Wondzell, 2011). Pools and riffles are often areas of increased hyporheic exchange and groundwater upwelling respectively (Burkholder et al., 2011). T3 displays this pool and riffle system near the middle well; a large pool where hyporheic exchange would dive into the subsurface appears just upstream 
of the well. If the flow path comes back to surface downstream of the well, an increased sense of upwelling would cool the temperatures observed at depth (Figure 14).

One consideration about the hyporheic data is the limited data collected at depth below the stream. Without any background knowledge about the site, wells were attempted to be installed at a depth of 1.5 meters as in Bastola (2011) and Beach (2008). A denser clay layer encountered at 0.5 -meters depth resulted in the redesign with a maximum depth of 0.4 meter. This infers a limited hyporheic zone beneath T3. The glacial till of the Wedron Group is likely the clay layer encountered at 0.5 meters under the streambed and the flow emerging from the temperature anomalies is controlled by spatial variations in hydraulic conductivity of the streambed sediments (Burkholder et al., 2008). The hyporheic zone may be deeper than the loggers placed at 0.4 meters would infer. Until the local groundwater flow paths can be confirmed and modelled, the thermal inputs of the hyporheic zone cannot be fully determined. Overall the groundwater has less of an effect on stream temperature than vice versa. The stream temperature shows limited sign of hyporheic zone influence qualitatively. The temperature regime of the hyporheic zone does propose that groundwater does have more influence on the stream temperatures than the tile-water does at the current discharge rates. 


\section{CHAPTER V CONCLUSIONS}

This study aimed to understand the hydrologic impact of a tile-drain on an agricultural stream in central Illinois and determine if the thermal impact of the tile-water and/or the groundwater was detectable on the streambed. In the end, the tile-drain influence on the stream was inconclusive but did correspond to a hydrologic change from no-flow events. The tile-water temperature showed a signature with elements similar to both the stream and groundwater observed temperatures (Figure 13). The streambed heat map signifies a thermal regime in equilibrium throughout the 60-metere array (Figure 12). The mixing model calculated an equilibrium temperature between the stream and tile-water temperature under the resolution of the data loggers; a product of the overwhelming volume difference between the stream discharge of T3 and the tile-drain. A theoretical volume flux was determined to be an order of magnitude greater than present at $\mathrm{T} 3$ to observe a decrease in stream temperature of $0.28^{\circ} \mathrm{C}$. The lack of consistent tile flow limits the effectiveness of the mixing model to compare the tile's thermal effect on the stream at various flow conditions.

Discharge and streambed temperatures indicate an area of thermal equilibrium at the streambed. Then beneath the streambed, an area of mixing between groundwater upwelling and hyporheic exchange steady the thermal signature up to a depth of 0.4 meters. 
The thermal envelopes (Figure 14) and difference in discharge across the array (Figure 11) suggest downwelling of stream water that overwhelms any groundwater upwelling signature in the hyporheic zone during the low-flow conditions when the warmest temperatures are observed. Spatial heterogeneities in the streambed are likely present with a thermal difference between the middle well and the other wells upstream and downstream; the middle well reflects an area of localized upwelling or suppressed downwelling similar to the conditions seen consistently during the coldest temperatures in the hyporheic zone. The thermal effect of the groundwater and the tile-water is minimal on the stream temperatures with the variance in fluxes. Overall, I would suggest that tile-drains would impact streambed temperatures at a greater flux or in a greater abundance in a designated area similar to that of this study at $\mathrm{T} 3$. 


\section{REFERENCES}

Anderson, M. P., 2005, Heat as a Ground Water Tracer. Groundwater, 43: 951-968. doi:10.1111/j.1745-6584.2005.00052.x

Arnold, J. G., and Allen, P. M., 1996, Estimating hydrologic budgets for three Illinois watersheds: Journal of Hydrology, v. 176, no. 1-4, p. 57-77.

Baskaran, S., Brodie, R. S., Ransley, T., and Baker, P., 2009, Time-series measurements of stream and sediment temperature for understanding river-groundwater interactions: Border Rivers and Lower Richmond catchments, Australia: Australian Journal of Earth Sciences, v. 56, no. 1, p. 21-30.

Bastola, H., 2011, Identifying seasonal changes in streambed thermal profile in a third order agricultural stream using 2D thermal modeling. [M.S.: Illinois State University, $56 \mathrm{p}$.

Beach, V., 2008, The impact of streambed sediment size on hyporheic temperature profiles in a low gradient third-order agricultural stream. [M.S.: Illinois State University, $128 \mathrm{p}$.

Beach, V. and Peterson, E., 2013, Variation of hyporheic temperature profiles in a low gradient Third-Order agricultural stream-A statistical approach, Open Journal of Modern Hydrology, Vol. 3 No. 2, pp. 55-66.

Burkholder, B. K., Grant, G.E., Haggerty, R., Khangaonkar, T., and Wampler, P.J., 2008, Influence of hyporheic flow and geomorphology on temperature of a large, gravelbed river, Clackamas River, Oregon, USA: Hydrologic Processes, v. 22, p. 941953, doi: 10.1002/hyp.6984

Casssie, D., Kurylyk, B., St-Hilaire, A., El-Jabi, N., MacQuarrie, K.,2014, Streambed temperature dynamics and corresponding heat fluxes in small streams experiencing seasonal ice cover: Journal of Hydrology, v. 519, p. 1441-1452, doi 10.1016

Changnon, S.A., Angel, J.R., Kunkel, K.E. and Lehmann, C.M., 2004.Climate atlas of Illinois. Illinois State Water Survey.

Conant Jr., B., 2004, Delineating and quantifying ground water discharge zones using streambed temperatures: Ground Water, v. 42, no. 2, p. 243-257.

Constantz, J., Cox, M. H., and Su, G. W., 2003a, Comparison of heat and bromide as ground water tracers near streams: Ground Water, v. 41, no. 5, p. 647-656. 
Constantz, J., Jasperse, J., Seymour, D., and Su, G. W., 2003b, Chapter 3 Heat tracing in the streambed along the Russian River of northern California, in Stonestrom, D. A., and Constantz, J., eds., Heat as a tool for studying the movement of ground water near streams, Volume U.S. Geological Survey Circular 1260: Denver, CO, U.S. Geological Survey, p. 17-20.

Constantz, J., and Stonestrom, D. A., 2003, Chapter 1 Heat as a tracer of water movement near streams, in Stonestrom, D. A., and Constantz, J., eds., Heat as a tool for studying the movement of ground water near streams, Volume U.S. Geological Survey Circular 1260: Denver, CO, U.S. Geological Survey, p. 1-6.

Constantz, J., Stonestrom, D., Stewart, A. E., Niswonger, R., and Smith, T. R., 2001, Analysis of streambed temperatures in ephemeral channels to determine streamflow frequency and duration: Water Resources Research, v. 37, no. 2, p. 317328, doi:

Dogwiler, T. J., and Wicks, C. M., 2006, Thermal variations in the hyporheic zone of a karst stream: International Journal of Speleology, v. 35, no. 2, p. 59-66. doi: 10.5038/1827-806X.35.2.1

Dahl, M., Nilsson, B., Langhoff, J. H., and Refsgaard, J. C., 2007, Review of classification systems and new multi-scale typology of groundwater-surface water interaction: Journal of Hydrology, v. 344, no. 1-2, p. 1-16.

Delsman, J. R., Waterloo, M. J., Groen, M. M. A., Groen, J., and Stuyfzand, P. J., 2014, Investigating summer flow paths in a Dutch agricultural field using high frequency direct measurements: Journal of Hydrology, v. 519, p. 3069-3085.

De Schepper, G., Therrien, R., Refsgaard, J. C., and Hansen, A. L., 2015, Simulating coupled surface and subsurface water flow in a tile-drained agricultural catchment: Journal of Hydrology, v. 521, p. 374-388.

Doucette, R., and Peterson, E., 2014, Identifying water sources in a karst aquifer using thermal signatures: Environmental Earth Sciences, v. 72, no. 12, p. 1-12.

Gentry, L.E., David, M.B., Smith-Starks, K.M., and Kovacic, D.A., 2000. Nitrogen Fertilizer and Herbicide Transport from Tile Drained Fields: Journal of $\begin{array}{lllll}\text { Environmental } \quad \text { Quality, } & \text { v. } & 29, & \text { p. }\end{array}$ doi:10.2134/jeq2000.00472425002900010030x

Glennon, C., 2008, Evaluating the role of sinuosity in the removal of nitrate from a third order agricultural stream in central Illinois. [MS: Illinois State University.

Groffman, P. M., Gold, A. J., and Simmons, R. C., 1992, Nitrate dynamics in riparian forests - microbial studies: Journal of Environmental Quality, v. 21, no. 4, p. 666671. 
Harris, J., 2008, Recovery of hyporheic function in agricultural streams over time, headwaters of the Mackinaw River, Illinois, USA [MS: Illinois State University, 74 p.

Hatch, C. E., Fisher, A. T., Revenaugh, J. S., Constantz, J., and Ruehl, C., 2006, Quantifying surface water-groundwater interactions using time series analysis of streambed thermal records: Method development: Water Resources Research, v. 42, no. W10410.

Hayden, K., 2012, Seasonal and diurnal variation of nitrate concentrations within the hyporheic zone of a low gradient, third-order stream in central Illinois. [MS: Illisnois State University.

Hill, A.R., 1996. Nitrate removal in stream riparian zones: Journal of Environmental. Quality, v. 25, p. 743- 755 .

Hsieh, P.A., Wingle, William, and Healy, R.W., 2000, VS2DI--A graphical software package for simulating fluid flow and solute or energy transport in variably saturated porous media: U.S. Geological Survey Water-Resources Investigations Report 99-4130, 16 p.

Johnson, W. H., and Hansel, A. K., 1999, Wisconsin Episode glacial landscape of central Illinois: A product of subglacial deformation processes?: Glacial Processes Past and Present, no. 337, p. 121-135.

Keery, J., Binleya, A., Crook, N., and Smith, J. W. N., 2007, Temporal and spatial variability of groundwater-surface water fluxes: Development and application of an analytical method using temperature time series: Journal of Hydrology, v. 336, no. 1-2, p. 1-16, doi: 10.1016/j.jhydrol.2006.1012.1003.

Klaus, J., Zehe, E., Elsner, M., Palm, J., Schneider, D., Schroder, B., Steinbeiss, S., van Schaik, L., and West, S., 2014, Controls of event-based pesticide leaching in natural soils: A systematic study based on replicated field scale irrigation experiments: Journal of Hydrology, v.512, p.528 -539, doi: 10.1016/j.jhydrol.2014.03.020

Lapham, W. W., 1989, Use of temperature profiles beneath streams to determine rates of vertical ground-water flow and vertical hydraulic conductivity, in Survey, U. S. G., ed., Volume Water-Supply Paper 2337: Reston, VA, United States Geological Survey, p. 35.

Lee, J. Y., Lim, H. S., Yoon, H. I., and Park, Y., 2013, Stream Water and Groundwater Interaction Revealed by Temperature Monitoring in Agricultural Areas: Water, v. 5, no. 4, p. 1677-1698.

Loheide, S.P., Gorelick, S.M., 2006, Quantifying stream-aquifer interactions through analysis of remotely sensed thermographic profiles and in-situ temperature records, Environmental Science \& Technology, 40, p. 3336-3341 
Lowry, C. S., Walker, J. F., Hunt, R. J., and Anderson, M. P., 2007, Identifying spatial variability of groundwater discharge in a wetland stream using a distributed temperature sensor: Water Resources Research, v. 43, no. W10408, p. 9.

Luhmann, A. J., Covington, M. D., Peters, A. J., Alexander, S. C., Anger, C. T., Green, J. A., Runkel, A. C., and E. Alexander Jr., C., 2010, Classification of Thermal Patterns at Karst Springs and Cave Streams: Ground Water.

Maguffin, S. C., 2006, The effects of altering land use on Wolf CreekMS]: Illinois State University.

McGrew, Jr., J. C. and Monroe, C. B., 2009, An Introduction to Statistical Problem Solving in Geography: Second Edition, Waveland Press, 254 p.

Mitchell, S., 1999, A Simple Model for Estimating Mean Monthly Stream Temperatures After Riparian Canopy Removal: Environmental Management, v. 24, no. 1, p. 7783.

Neumann, D. W., Rajagopalan, B., and Zagona, E. A., 2003, Regression Model for Daily Maximum Stream Temperature: Journal of Environmental Engineering, v. 129, no. 7, p. 667-674.

Oware, E., 2010, The impact of storm on thermal transport in the hyporheic zone of a lowgradient third-order sand and gravel bedded stream. [M.S.: Illinois State University, $74 \mathrm{p}$.

Poole, G. C., and Berman, C. H., 2001, An Ecological Perspective on In-Stream Temperature: Natural Heat Dynamics and Mechanisms of Human-Caused Thermal Degradation: Environmental Management, v. 27, no. 6, p. 787-8002.

Ronan, A. D., Prudic, D. E., Thodal, C. E., and Constantz, J., 1998, Field study and simulation of diurnal temperature effects on infiltration and variably saturated flow beneath an ephemeral stream: Water Resources Research, v. 34, p. 2137-2153.

Self, J.R., Waskom, R. M., 2013, Nitrates in drinking water: Colorado State University Fact Sheet, no. 0.517.

Sickbert, T. B., 2004, An examination into the physical controls of hyporheic exchange [MS: Illinois State University.

Sickbert, T. B., and Peterson, E. W., 2014, The effect of surface water velocity on hyporheic interchange: Journal of Water Resource and Protection, v. 6, no. 4, p. 327-336.

Silliman, S. E., and Booth, D. F., 1993, Analysis of time-series measurements of sediment temperature for identification of gaining vs. losing portions of Juday Creek, Indiana: Journal of Hydrology, v. 146, no. 1-4, p. 131-148.

Sinokrot, B. A., and Stefan, H.G., 1993, Stream temperature dynamics: measurements and modeling: Water Resources Research, v. 29, no. 7, p. 2299-2313. 
Skaggs, R. W., Brevé, M.A., and Gilliam, J.W., 1994, Hydrologic and water-quality impacts of agricultural drainage: Critical reviews in environmental science and technology, v. 24, no. 1, p. 1-32.

Sophocleous, M., 2002, Interactions between groundwater and surface water: the state of the science: Hydrogeology Journal, v. 10, no. 1, p. 52-67.

Stonestrom, D. A., and Constantz, J., 2004, Using temperature to study stream-ground water exchanges, in Survey, U. S. G., ed., Volume Fact Sheet - U. S. Geological Survey, U. S. Geological Survey, p. 4.

Theesfeld, K., 2014, Nitrate uptake in central Illinois streams: a comparison along a transient storage gradient. [MS: Illinois State University.

Urban M.A. and Rhoads B.L., 2003, Catastrophic Human-Induced Change in StreamChannel Planform and Geometry in an Agricultural Watershed, Illinois, USA, Annals of the Association of American Geographers 93(4): 783-796

U.S. Geological Survey, 2009, A Whole-System Approach to Understanding Agricultural Chemicals in the Environment: U.S. Geological Survey National Water-Quality Assessment Program, Agricultural Chemicals Team website, accessed February 28, 2016, at http://pubs.usgs.gov/fs/2009/3042/.

Weedman, N.R., Malone, D.H., and Shields, W.E., 2014, Surficial Geology of Normal West 7.5-minute Quadrangle, McLean County, Illinois, Illinois State Geological Survey: https://www.isgs.illinois.edu/maps/isgs-quads/surficial-geology/normalwest Illinois State Geological Survey

White A.B., Kumar P., Saco P.M., and Rhoads B.L., Yen BC., 2003, Changes in hydrologic response due to stream network extension via land drainage activities: Journal of the American Water Resources Association, vol. 39, no. 6, p. 1547-1560

Winter, T. C., 1998, Ground Water and Surface Water: A Single Resource, U S Geological Survey., 1999, Relation of streams, lakes, and wetlands to groundwater flow systems: Hydrogeology Journal, v. 7, no. 1, p. 28-45.

Wondzell, S.M., 2011, The role of Hyporheic zone across stream networks: Hydrologic Processes, v. 25, no. 1, p. 3525-3532, doi: 10.1002/hyp.8119.

WWAP (World Water Assessment Programme). 2012. The United Nations World Water Development Report 4: Managing Water under Uncertainty and Risk. Paris, UNESCO.

Zajicek, A., Kvitek, T., Kaplicka, M., Dolezal, F., Kulhavy, Z., Bystricky, V., and Zlabek, P., 2011, Drainage water temperature as a basis for verifying drainage runoff composition on slopes: Hydrological Processes, v. 25, no. 20, p. 3204-3215. 